\title{
PERANCANGAN SISTEM PAKAR DIAGNOSA PENYAKIT LUPUS ERITMATOSUS SISTEM(LES) DENGAN METODE FORWARD CHAINING MENGGUNAKAN PEMROGRAMAN PHP DAN MYSQL
}

\author{
Novi Yona Sidratul Munti \\ Pasca Sarjana, Universitas Putra Indonesia "YPTK" Padang \\ e-mail: sikumbang_ona@yahoo.com
}

\begin{abstract}
Tujuan penelitian adalah merancang dan membangun rekayasa perangkat lunak sistem pakar berbasis web yang mampu mendiagnosa penyakit Lupus Eritmatosus Sistem (LES) pada manusia untuk mendapatkan solusi dan informasi dengan mudah dan cepat. Hasil yang ditampilkan berupa kondisi user terkait dengan Lupus Eritmatosus Sistem (LES) . Hasil juga dilengkapi dengan penjelesan penyakit dan solusi pengobatan yang ditampilkan dalam bentuk website menggunakan pemrograman PHP dengan database MySQL. Kesimpulan dalam penelitian ini adalah bahasa pemograman PHP dan MySQL terbukti mampu diimplementasikan dalam merekayasa sistem pakar untuk mendiagnosa penyakit Lupus Eritmatosus Sistem (LES). Metode fordward chaining terbukti mampu melakukan penelusuran /pelacakan gejala penyakit Lupus Eritmatosus Sistem (LES) dengan mudah dan cepat. Sistem online dapat membantu user mendapatkan informasi tentang jenis-jenis penyakit, gejala dan solusi pengobatan pada penyakit Lupus Eritmatosus Sistem (LES)..
\end{abstract}

Kata kunci: Sistem pakar, Lupus Eritmatosus Sistem (LES), Fordward Chaining, PHP MySQL

\section{PENDAHULUAN}

Pada masa era globalisasi sekarang ini perkembangan tekhnologi khususnya komputer sudah banyak dimanfaatkan pada perusahaan atau pun dibidang ilmu pengetahuan. Dengan demikian peranan tekhnologi informasi itu sangat penting dalam setiap aspek kehidupan, baik itu dalam bidang ekonomi, ilmu pengetahuan, Pemerintah dan bidang tekhnologi itu sendiri.

Sistem pakar adalah Program berbasis pengetahuan yang menyediakan solusi-solusi dengan kualitas pakar untuk masalah yang spesifik. Sistem pakar merupakan Program komputer yang meniru proses pemikiran dan pengetahuan pakar dalam menyelesaikan suatu masalah tertentu. Perancangan sistem pakar banyak digunakan dalam bidang kesehatan karena sistem pakar dipandang sebagai cara penyimpanan pengetahuan pakar pada bidang tertentu dalam Program komputer sehingga keputusan dapat diberikan dalam melakukan penalaran secara cerdas.

Lupus adalah Penyakit Autoimun yang muncul ketika tubuh terkena zat asing tertentu, seperti Bakteri dan Virus. Penyakit Lupus adalah peradangan kronis yang terjadi ketika sistem imun tubuh menyerang organ dan jaringan tubuh. Peradangan yang disebabkan oleh lupus dapat berefek pada berbagai sistem di dalam tubuh,antara lain Sendi, Kulit, Ginjal, Sel Darah, Jantung dan Paru-Paru.

Berdasarkan permasalahan di atas maka penulis tertarik mengangkat permasalahan tentang Lupus dan direalisasikan kedalam bentuk Skripsi yang diberi Judul :" PERANCANGAN SISTEM PAKAR DIAGNOSA PENYAKIT LUPUS ERITMATOSUS SISTEM (LES) DENGAN METODE FORWARD CHAINING MENGGUNAKAN PEMROGRAMAN PHP DAN MYSQL “.

\section{KAJIAN LITERATUR}

\subsection{Rekayasa Perangkat Lunak (RPL)}

Rekayasa Perangkat lunak adalah seluruh perintah yang digunakan untuk memproses informasi. Perangka lunak dapat berupa program atau prosedur.Program adalah kumpulan perintah yang dimengerti oleh komputer sedangkan perosedur adalah perintah yang dibutuhkan oleh pengguna dalam memproses informasi (O’Brien,1999). Pengertian RPL sendiri adalah sebagai berikut: Suatu disiplin ilmu yang membahas semua aspek produksi perangkat lunak, mulai 
dari tahap awal yaitu analisa kebutuhan pengguna, menentukan spesifikasi dari kebutuhan pengguna, disain , pengkodean, pengujian sampai pemeliharaan sistem setelah digunakan (Mulyanto, 2008 :2)

Karakteristik Perangkat Lunak lebih dikenal sebagai elemen logik dari pada fisik, oleh karena itu perangkat lunak memiliki karakteristik yang berbeda dari perangkat keras :

1. Perangkat lunak dikembangkan atau direkayasa, jadi tidak diproduksi dalam pengertian klasik.

2. Merupakan produk yang unik (tidak ada seri produksi).

3. Perangkat lunak tidak pernah akan rusak atau aus karena selalu diperbaharui

4. Tidak terlihat (invisible).

5. Perangkat lunak pada umumnya dibangun sesuai keinginan, jadi tidak dibentuk

6. dari komponen yang sudah ada.

7. Fleksibel, sehingga mudah dimodifikasi.

8. Dihubungkan (linked) dengan sistem komputer.

\subsubsection{Tujuan Rekayasa Perangkat lunak}

Secara umum tujuan rekayasa perangkat lunak tidak berbeda dengan rekayasa yang lain, menurut Mulyanto (2008:2) mengungkapkan: "tujuan dari rekayasa perangkat lunak" adalah sebagai berikut:

1. Memperoleh biaya produksi perangkat lunak yang rendah.

2. Menghasilkan perangkat lunak yang kinerjanya tinggi, handal dan tepat waktu.

3. Menghasilkan perangkat lunak yang dapat bekerja pada berbagai jenis platform.

4. Menghasilkan perangkat lunak yang biaya perawatannya rendah.

5. Mampu melaksanakan analisis kebutuhan, perancangan, implementasi dan pengujian perangkat lunak dengan pendekatan terstruktur.

6. Mampu menyusun dokumentasi pengembangan perangkat lunak.

\subsection{Sejarah Singkat Artificial intelegence}

Kecerdasan Buatan (artificial

intelligence) merupakan inovasi baru dibidang ilmu pengetahuan. Pada tahun 1950-an para ilmuan dan peneliti mulai memikirkan bagaimana cara agar mesin dapat melakukan pekerjaan seperti yang biasa dilkukan para manusia. Alan Turing, seorang matematikawan dari Inggris pertama kali menggusulkan adanya tes untuk melihat bisa tidaknya sebuah mesin dikatakan cerdas. Hasil tes tersebut kemudian dikenal Turing Tes, dimana si mesin tersebut menyamar seolah-olah sebagai seorang didalam suatu permainan yang mampu memberikan respon terhadap serangkaian pertanyaan yang diajukan. Turing beranggapan bahwa jika mesin dapat membuat seorang percaya bahwa dirinya mampu berkomunikasi dengan orang lain, maka dapat dikatakan bahwa mesin tersebut cerdas (seperti layaknya manusia).

Kecerdasan buatan atau "Artificial Intelligence " itu sendiri dimunculkan oleh seorang profesor dari Massaachusetts Institute of Techonology yang bernama John McCarthy pada tahun 1956 pada Dartmouth Conference yang dihadiri para peneliti AI. Pada konferensi tersebut juga didefinisikan tujuan utama dari kecerdasan buatan, yaitu: mengetahui dan memodelkan proses-proses berfikir manusia dan mendesain mesin agar dapat menirukan kelakuan manusia tersebut.

Pada awalnya, kecerdasan buatan hanya ada di Universitas-Universitas dan laboratorium penelitian, serta hanya sedikit produk yang dihasilkan dan dikembangkan. Menjelang akhir 1970-an dan 1980-an, mulai dikembangkan secara penuh dan hasilnya berangsur-angsur dipublikasikan di khalayak umum. Permasalahan di dalam kecerdasan buatan akan selalu bertambah dan berkembang seiring dengan laju perkembangan zaman menuju arah globalisasi dalam setiap aspek kehidupan manusia, yang membawa persoalan-persoalan yang semakin beragam pula. Program kecerdasan buatan lebih sederhana dalam pengoperasiannya, sehingga banyak membantu pemakai. Program konvensional dijalankan secara prosedural dan kaku, rangkaian tahap solusinya sudah didefinisikan secara tepat oleh pemrogramnya. Sebaliknya, pada program kecerdasan buatan untuk mendapatkan solusi yang memuaskan dilakukan pendekatan trial and error, mirip seperti apa yang dilakukan oleh manusia (Anita desiani, Arhami, 2005).

\subsubsection{Defenisi Kecerdasan Buatan (Artificial Intelligence) \\ Definisi kecerdasan buatan yang telah} didefinisikan oleh beberapa ahli:

1. H. A. Simon (1987) :

"Kecerdasan buatan (Artificial Intelligence) merupakan kawasan penelitian, aplikasi dan instruksi yang terkait dengan pemrograman komputer untuk melakukan sesuatu hal yang dalam pandangan manusia adalah cerdas".

2. Rich and Knight (1991):

"Kecerdasan Buatan (Artificial Intelligence) merupakan sebuah studi tentang bagaimana membuat komputer melakukan hal- 
hal yang pada saat ini dapat dilakukan lebih baik oleh manusia".

3. Encyclopedia Britannica:

"Kecerdasan Buatan (Artificial Intelligence) merupakan cabang dari ilmu komputer yang dalam merepresentasi pengetahuan lebih banyak menggunakan bentuk simbol-simbol daripada bilangan, dan memproses informasi berdasarkan metodeheuristic atau dengan berdasarkan sejumlah aturan" (Sutojo, Mulyanto dan Suhartono, 2010).

4. Rich and Knight (1991):

"Kecerdasan buatan (Artificial Intelligence) merupakan sebuah studi tentang bagaimana membuat komputer melakukan halhal yang saat ini dapat dilakukan lebih baik oleh manusia".

Kecerdasan tiruan (Artificial Intelligence) adalah suatu area dalam ilmu komputer. Istilah tersebut mencakup banyak definisi (Ray, 1996) tetapi sebagian pakar setuju bahwa kecerdasan tiruan (Artificial Intelligence) berkaitan dengan dua ide dasar. Pertama, ide yang melibatkan pembelajaran proses pemikiran manusia (untuk memahami apa yang dimaksud dengan kecerdasan); kedua, berkaitan dengan representasi dan duplikasi proses tersebut melalui mesin (misalnya, komputer dan robot).

Kecerdasan tiruan juga merupakan tingkah laku mesin yang jika dilakukan

oleh manusia akan disebut cerdas. Suatu definisi yang membangkitkan pemikiran dinyatakan oleh Rich dan Knight (1991): "Kecerdasan tiruan adalah studi tentang bagaimana membuat komputer melakukan hal yang pada saat itu lebih baik dilakukan oleh manusia".

Bidang-bidang kecerdasan tiruan (Turban, 2005) adalah:

1. Sistem Pakar

2. Pemrosesan Bahasa Alami

3. Speech (Voice) Understanding

4. Sistem Robotik dan Sistem Sensor

5. Computer Vision dan Recognition

6. Intelligent Computer-Aided Instruction

7. Komputasi Saraf

8. Game Playing

\subsection{Sistem Pakar (Expert System)}

Sistem pakar dapat membantu aktivitas para pakar sebagai asisten yang berpengalaman dan mempunyai pengetahuan yang dibutuhkan. Dalam penyusunannya, sistem pakar mengkombinasikan kaidah-kaidah penarikan kesimpulan (inference rules) dengan basis pengetahuan tertentu yang diberikan oleh satu atau lebih pakar dalam bidang tertentu. Kombinasi dari kedua hal tersebut disimpan dalam basis pengetahuan, yang selanjutnya digunakan dalam proses pengambilan keputusan untuk penyelesaian masalah tertentu.

Biasanya pakar manusia mampu melakukan hal berikut : Mengenali dan merumuskan persoalan, Memecahkan persoalan dengan cepat dan tepat, Menjelaskan solusi tersebut, Belajar dari pengalaman, Menyusun ulang pengetahuan, Membagi-bagi aturan jika diperlukan, Menetapkan relevansi Keahlian adalah pengetahuan ekstensif yang spesifik terhadap tugas yang dimiliki pakar.

Keahlian sering dicapai dari pelatihan, membaca, dan mempraktikkan. Keahlian mencakup pengetahuan eksplisit, misalnya teori yang dipelajari dari buku teks atau kelas, dan pengetahuan implisit yang diperoleh dari pengalaman. Pengembangan sistem pakar dibagi menjadi dua generasi. Kebanyakan sistem pakar generasi pertama menggunakan aturan jika-maka untuk merepresentasikan dan menyimpan pengetahuannya. Sistem pakar generasi kedua jauh lebih fleksibel dalam mengadopsi banyak representasi pengetahuan dan metode pertimbangan.

Ada beberapa definisi tentang sistem pakar :

1. Menurut Durkin: sistem pakar adalah suatu program komputer yang dirancang

untuk memodelkan kemampuan penyelesaian

masalah yang dilakukan oleh seorang pakar.

2. Menurut Ingizio: sistem pakar adalah suatu model dan prosedur yang berkaitan,

dalam suatu domain tertentu, yang mana tingkat keahlianya dapat dibandingkan

dengan keahlian seorang pakar.

3. Menurut Giarratano dan Riley: sistem pakar adalah suatu sistem komputer

yang bisa menyamai atau meniru kemampuan seorang pakar.

Sistem pakar menurut Turban (1995). Disusun oleh dua bagian utama, yaitu lingkungan pengembangan (development environment) dan lingkungan konsultasi (consultationenvironment).Lingkunganpengemb angan sistem pakar digunakan untuk memasukkan

pengetahuan pakar ke dalam lingkungan siste m pakar, sedangkan lingkungan konsultasi digunakan oleh pengguna yang bukan pakar guna memperoleh pengetahuan pakar.

\subsubsection{Manfaat Sistem pakar}

Manfaat dari sistem pakar antara lain : 
1. Memungkinkan orang awam mengerjakan pekerjaan orang ahli.

2. Bisa melakukan proses secara berulang secara otomatis .

3. Menyimpan pengetahuan dan keahlian orang pakar.

4. Mampu dan mengambil dan melestarikan keahlihan para pakar (terutama termasuk

keahlian yang langka ).

5. Mampu beroperasi dalam lingkungan yang berbahaya.

6. Tidak memerlukan biaya pada saat tidak digunakan, sedangkan pada pakar manusia sehari-hari memerlukan biaya.

7. Dapat digandakan (diperbanyak ) sesuai kebutuhan dengan waktu yang minimal dan sedikit biaya.

8. Dapat memecahkan masalah lebih cepat daripada kemampuan manusai dengan catatan menggunakan data yang sama .

9. Menghemat waktu dalam penggambilan keputusan.

10. Meningkatkan kreativitas dan produktifitas karna dapat memberi nasehat yang konsisten dan mengurangi masalah.

11. Meningkatkan kapabilitas sistem terkomputerissasi yang lain. integrasi Sistem

Pakar dengan sistem komputer lain membuat lebih efektif, dan bisa mencakup lebih banyak aplikasi.

12. Mampu menyediakan pelatihan. pengguna pemula yang berkerja dengan Sistem

Pakar akan menjadi lebih berpengalaman.

Fasilitas penjelas dapat berfungsi sebagai guru.

\subsubsection{Ciri-ciri Sistem Pakar}

Menurut Arhami, Muhamad (2005), dalam pembuatan sistem pakar harus diketahui ciri-ciri dan kategori masalah sistem pakar. Pada umumnya sistem pakar bersifat:

1. Memiliki informasi yang handal, baik dalam menampilkan langkah-langkah antara

maupun dalam menjawab pertanyaanpertanyaan tentang proses penyelesaian.

2. Mudah dimodifikasi, yaitu dengan menambah atau menghapus suatu kemampuan

dari basis pengetahuannya.

3. Dapat digunakan dalam berbagai jenis komputer.

4. Memiliki kemampuan untuk beradaptasi.

Selain Arhami (Kusrini, 2008) juga menyatakan beberapa ciri-ciri dari sistem pakar, yaitu :

1. Terbatas pada bidang keahlian yang spesifik.

2. Dapat mengemukakan rangkaian alasanalasan yang diberikan dengan cara yang

Dapat dipahami.
3. Dapat memberikan penalaran untuk data-data yang tidak lengkap atau tidak pasti.

4. Berdasarkan rule atau kaidah tertentu.

5. Dirancang untuk dikembangkan secara bertahap.

6. Keluaran bersifat anjuran atau nasehat.

7. Keluaran tergantung dari dialog dengan user.

\subsubsection{Keuntungan Sistem Pakar}

Ada beberapa kelebihan yang dapat diperoleh dari pembuatan sistem pakar menurut Arhami, Muhamad (2005), yaitu:

1. Menjadikan pengetahuan dan nasihat lebih mudah didapat.

2. Meningkatkan output dan produktivitas.

3. Menyimpan kemampuan dan keahlian pakar.

4. Meningkatkan reabilitas.

5. Memberikan respons (jawaban) yang cepat.

6. Merupakan panduan yang cerdas.

7. Dapat bekerja dengan informasi yang kurang lengkap dan mengandung ketidakpastian.

8. Basis data cerdas, bahwa sistem pakar dapat digunakan untuk mengakses basis data dengan cara cerdas.

\subsubsection{Kelemahan Sistem Pakar}

Selain sistem pakar mempunyai kelebihan, menurut Arhami, Muhamad (2005), sistem pakar juga mempunyai kelemahan, yaitu:

1. Masalah dalam mendapatkan pengetahuan di mana pengetahuan tidak selalu bisa didapatkan dengan mudah, karena kadangkalapakar dari masalah yang kita buat tidak ada, dan kalaupun ada kadangkadang pendekatan yang dimiliki oleh pakar berbeda-beda.

2. Untuk membuat suatu sistem pakar yang benar-benar berkualitas tinggi sangatlah sulit dan memerlukan biaya yang sangat besar untuk pengembangan dan pemeliharaanya.

3. Boleh jadi sistem pakar tidak dapat membuat keputusan.

4. Sistem pakar tidak $100 \%$ menguntungkan, karena seseorang yang telibat dalam sistem pakar tidak selalu benar. Oleh karena itu perlu diuji ulang secara teliti sebelum digunakan.

\subsubsection{Komponen Sistem Pakar}

Menurut (Kusrini, 2008). Komponen utama pada sistem pakar meliputi:

1. Basis Pengetahuan (Knowledge Base)

Basis pengetahuan merupakan inti dari suatu sistem pakar, yaitu berupa representasi 
pengetahuan dari pakar. Basis pengetahuan tersusun atas fakta dan kaidah. Fakta adalah informasi tentang objek, peristiwa, atau situasi. Kaidah adalah cara untuk membangkitkan suatu fakta baru dari fakta yang sudah diketahui.

2. Mesin Inferensi (Inference Engine)

Mesin inferensi berperan sebagai otak dari sistem pakar. Mesin inferensi berfungsi untuk memandu proses penalaran terhadap suatu kondisi, berdasarkan pada basis pengetahuan yang tersedia. Di dalam mesin inferensi terjadi proses untuk memanipulasi dan mengarahkan kaidah, model, dan fakta yang disimpan dalam basis pengetahuan dalam rangka mencapai solusi atau kesimpulan. Dalam prosesnya, mesin inferensi menggunakan strategi penalaran dan strategi pengendalian. Strategi penalaran terdiri dari strategi penalaran pasti (Exact Reasoning) dan strategi penalaran tak pasti (Inexact Reasoning). Exact reasoning akan dilakukan jika semua data yang dibutuhkan untuk menarik suatu kesimpulan tersedia, sedangkan inexact reasoning dilakukan pada keadaan sebaliknya. Strategi pengendalian berfungsi sebagai panduan arah dalam melakukan proses penalaran. Terdapat tiga teknik pengendalian yang sering digunakan, yaitu forward chaining, backward chaining, dan gabungan dari kedua tehnik pengendalian tersebut.

\section{Basis Data (Data Base)}

Basis data terdiri atas semua fakta yang diperlukan, di mana fakta-fakta tersebut digunakan untuk memenuhi kondisi dari kaidahkaidah dalam sistem. Basis data menyimpan semua fakta, baik fakta awal pada saat sistem mulai beroperasi, maupun fakta-fakta yang diperoleh pada saat proses penarikan kesimpulan sedang dilaksanakan. Basis data digunakan untuk menyimpan data hasil observasi dan data lain yang dibutuhkan selama pemrosesan.

\subsubsection{Klasifikasi Sistem Pakar}

Berdasarkan kegunaannya Arhami, Muhamad (2005),sistem pakar dapat diklasifikasikan menjadi sebagai berikut:

1. Diagnosis.

Sistem ini digunakan untuk memecahkan atau menemukan masalah atau kerusakan yang sedang terjadi.

2. Pengajaran.

Sistem ini digunakan untuk proses belajar mengajar, sistem ini diharapkan dapat mengetahui letak dan memberikan cara untuk memperbaiki kekurangan tersebut.

3. Interpretasi
Digunakan untuk menganalisa data yang tidak lengkap, tidak teratur, dan juga kontradiktif.

4. Prediksi

Kemampuan untuk memprediksi yang akan terjadi.

5. Perencanaan

Kemampuan untuk merencanakan sistem yang akan dipakai.

6. Kontrol

Digunakan untuk mengontrol kegiatan yang membutuhkan ketepatan waktu tinggi.

Terdapat dua pendekatan untuk mengontrol inferensi dalam sistem pakaberbasis aturan, yaitu:

1. Pelacakan Kebelakang (Backward
Chaining).

Pelacakan kebelakang adalah pendekatan yang dimotori tujuan (goaldriven).Dalam pendekatan ini pelacakan dimulai dari tujuan, selanjutnya dicari aturan yang memiliki tujuan tersebut untuk kesimpulannya. Selanjutnya proses pelacakan menggunakan premis untuk aturan tersebut sebagai tujuan baru dan mencari aturan lain dengan tujuan baru sebagai kesimpulannya. Proses berlanjut sampai semua kemungkinan ditemukan (Arhami, 2005). dibawah ini:

Prosesnya diperlihatkan pada gambar

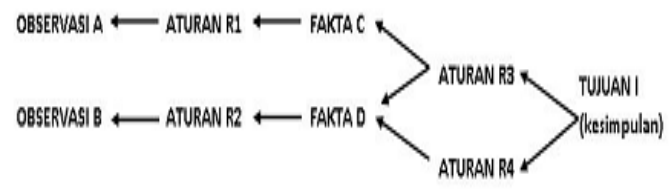

Gambar 2.1 Proses Backward Chaining

2. Pelacakan Kedepan (Forward Chaining).

Pelacakan kedepan(forward chaining) adalah pendekatan yang dimotori data (datadriven). Dalam pendekatan ini pelacakan dimulai dari informasi masukan dan selanjutnya mencoba menggambarkan kesimpulan, pelacakan kedepan mencari fakta yang sesuai dengan bagian IF dari aturan IF-THEN. Prosesnya ditunjukkan pada gambar dibawah ini:

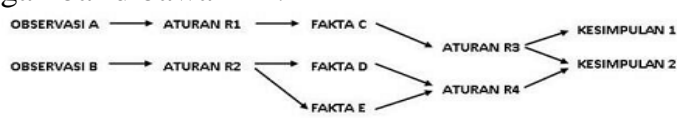

\section{Gambar 2.2 Proses Forward Chaining}

Kedua metode inferensi tersebut dipengaruhi oleh tiga macam penelusuran, yaitu : a. Depth-First Search

Melakukan penelurusan kaidah secara mendalam dari simpul akar bergerak menurun ke tingkatan dalam yang berurutan. 


\section{Gambar 2.3 Diagram alir teknik penelusuran Depth-first search}

\section{b. Breadth-First Fearch}

Bergerak dari simpul akar, simpul yang ada pada setiap tingkat diuji sebelum pindah ke tingkat selanjutnya.

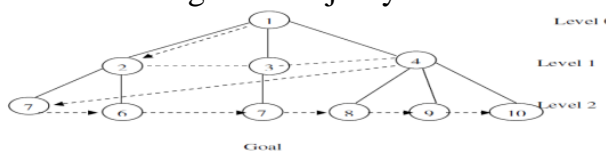

Gambar 2.4 Diagram alir teknik penelusuran Breadth-first fearch

c. Best-First Search (BFS)

Metode yang membangkitkan simpul dari simpul sebelumnya. Best-first search memilih simpul baru yang memiliki biaya terkecil diantara semualeaf nodes (simpulsimpul pada level terdalam) yang pernah dibangkitkan.

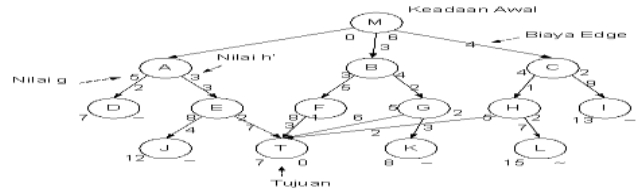

Gambar 2.5 Diagram alir teknik penelusuran Best-first search

\section{d. Workplace}

Merupakan area dari sekumpulan memori kerja (working memory). Workplace digunakan untuk merekan antara hasil kesimpulan yang dicapai.

\section{a. Fasilitas Penjelasan}

Merupakan komponen tambahan yang akan meningkatkan kemampuan sistem pakar. Komponen ini menggambarkan penalaran sistem kepada pemakai.

\section{b. Perbaikan Pengetahuan}

Pakar memiliki kamampuan untuk menganalisis dan meningktakan kinerjanya serta kemampuan untuk belajar dari kinerjanya. Kemapuan tersebut adalah penting dalam pembelajaran terkomputerisasi, sehingga program mampu menganalisis penyebab kesuksesan dan kegagalan yang dialaminya (Arhami, 2005).

\subsection{Sekilas Tentang Web}

Web adalah salah satu aplikasi yang berisikan dokumen-dokumen multi media (teks, gambar, suara, animasi, vidio ) di dalamnya yang menggunakan protokol HTTP (hypertext tnasfer frotocol) dan untuk mengaksesnya menggunakan perangkat lunak yang di sebut browser (Rudyanto Arief, 2001). Beberapa jenis browser yang populer saat ini adalah: internet Explorer yang di produksi oleh microsoft, mozilla Firefok, dan Safari yang di produksi oleh Apple.

Browser (perambah) adalah aplikasi yang mampu menjalankan dokumen-dokumen web dengan cara di terjemaahkan. Prosesnya di lakukan oleh komponen yang terdapat di dalam aplikasi browser yang biasa di sebut web enggine. Semua dokumen web di tampilkan oleh browser dengan cara di terjemahkan (Rudyanto Arief, 2001)

Situs web adalah dokumen-dokumen web yang terkumpul menjadi satu kesatuan yang memiliki Unifed Resource Locator (URL) atau domain dan biasanya di-publish di internet atau intranet (Rudyanto Arief, 2001).

Sebelum mulai membuat desain tampilan web, ada baiknya memahami lebih dahulu fungsi sebuah website, sehingga desain yang dibuat disesuaikan dengan fungsi website tersebut. Jasmadi (2004) mengungkapkan: "secara umum website mempunyai fungsi", yaitu:

1. Fungsi Komunikasi

Sebagian besar website mempunyai fungsi komunikasi. Beberapa fasilitas yang memberikan fungsi komunikasi ini, seperti : web base email, halaman form contact, chatting dan lain-lain.

2. Fungsi Informasi

Website mempunyai fungsi informasi seperti news, profile company, library, referensi, dan lain-lain.

3. Fungsi Entertainment

Website mempunyai fungsi hiburan. Beberapa contoh website dengan fungsi ini, misalnya web-web yang menyediakan online game, online music, online movie, dan sebagainya.

4. Fungsi Transaksi

Sebuah website dapat dijadikan saran untuk melakukan transaksi bisnis, seperti : online order,pembayaran menggunakan kartu kredit, dan lain-lain.

"Sebuah website dapat dijadikan sarana untuk melakukan transaksi bisnis, seperti: online order, pembayaran menggunakan kartu kredit, dan lain-lain" (Jasmadi, 2004).

Website atau situs juga dapat diartikan sebagai kumpulan halaman yang menampilkan informasi data teks, data gambar diam atau gerak, data animasi, suara, video dan atau gabungan dari semuanya, baik yang bersifat statis maupun dinamis yang membentuk satu rangkaian bangunan yang saling terkait dimana masing-masing dihubungkan dengan jaringanjaringan halaman (hyperlink). 


\subsection{Personal Home Page (PHP)}

PHP merupakan bahasa (scripting language) yang ditempelkan (embedded) ketika digunakan dalam halaman web. Maksudnya adalah bahwa kode PHP ditempelkan di dalam kode html (Rulianto kurniawan, 2010). Software PHP bekerja bersama dengan Web Server. Web Server adalah software yang mengirim halaman web kepada dunia.

Javascript adalah bahasa skrip yang ditempelkan pada kode HTML dan diproses di sisi klien. Dengan adanya bahasa ini, kemampuan dokumen HTML menjadi semakin luas (Rulianto kurniawan, 2010). Sebagai contoh, dengan menggunakan JavaScript dimungkinkan untuk memvalidasi masukan-masukan pada formulir sebelum formulir dikirimkan ke server. Javascript bukanlah bahasa Java dan merupakan dua bahasa yang berbeda. Javascript diinterpretasikan oleh klien (kodenya bisa dilihat pada sisi klien), sedangkan kode Java dikompilasi oleh pemrogram dan hasil kompilasinyalah yang dijalankan oleh klien.

Selain dari php juga terdapat suatu system yang di namakan Cascading Style Sheet (CSS).Cascading Style Sheet (CSS) merupakan sebuah document yang berguna untuk melakukan pengaturan pada komponen halaman web, inti dari document ini adalah memformat halaman web standar menjadi bentuk web yang memiliki kualitas yang lebih indah dan menarik. CSS biasanya digunakan untuk melakukan pengaturan global yang berkaitan dengan objek tetap, misalnya memberikan warna pada halaman web, pengaturan lebar dan kecil bagian web serta menentukan bentuk font jenis huruf yang digunakan secara menyeluruh dalam halaman web.

\subsubsection{Pengenalan PHP}

PHP merupakan perangkat lunak open source, yang mana penulisan kode program $P H P$ menyatu dengan HTML yang berjalan pada server-side. Hal ini berarti semua sintak yang telah ditulis akan sepenuhnya dijalankan pada server; hanya hasil dari script yang telah dieksekusi saja yang dikirimkan pada sisi client/ browser tanpa bisa mengetahui kode yang digunakan. PHP merupakan bahasa pemograman yang sesuai untuk membuat aplikasi website dinamis seperti $C M S$ karena memiliki performa yang tinggi, mudah dipelajari, multiplatform, aman, open source, serta mudah dikoneksikan dengan berbagai macam database.

Dan dengan pengembangan yang dilakukan $P H P$ kini memiliki kinerja yang lebih tinggi daripada versi-versi sebelumnya, berkemampuan OOP (Object Oriented Programming), syntax highlighting, array multidimensi, dan dapat diperluas melalui mekanisme extension. PHP merupakan salah satu bahasa Server-Side yang didesain khusus untuk perancangan aplikasi web dan tergolong aman untuk digunakan.

\subsubsection{Sejarah PHP}

"Rasmus Lardorf merasa kurang puas dengan sistem yang ada pada saat itu, sehingga dia menciptakan suatu model interface (antar muka) yang dapat digunakan untuk menampung informasi tentang para pengunjung situsnya. Pertama kali, Rasmus membuat interface dengan menggunakan PERL dan selanjutnya dia mengembangkan dengan menggunakan bahasa $\mathrm{C}$ untuk memberikan fleksibilitas pada interface/ parser tersebut" (Sakur, 2010).

Pada mulanya, interface tersebut diberi nama Personal Home Page, yang memiliki kemampuan untuk mencatat seluruh informasi dari pengunjung situs online-nya. Kemudian, interface atau parser tersebut dimodifikasi dengan mendukung database $m S Q L$ atau Mini Structure Query Language dengan menggunakan parser $S Q L$, pengembangan ini diberi nama $F I$ (Form Interpreter). Kemudian PHP/FI version 2.0 diluncurkan dan merupakan awal kelahiran dari $P H P$ yang saat ini sudah mencapai versi 5.x.x. Selanjutnya $P H P$ ini dikembangkan oleh tim untuk memberikan kemampuan yang seimbang dengan aplikasi lainnya.

"Saat ini, Zend menjadi pengembang utama dan telah mendistribusikan Zend Enginenya untuk perkembangan PHP. Sampai sekarang, penggunaan PHP sudah sangat banyak karena kemudahan dan keandalannya di dalam proses pemograman" (Saputra, 2010).

\subsubsection{Kelebihan PHP}

Saputra (2010) mengungkapkan: "dalam penggunaan PHP ini memiliki kelebihan atau keunggulan", seperti berikut:

1. Mudah dipelajari, alasan tersebut menjadi salah satu alasan utama untuk

menggunakan PHP. Karena baik pemula ataupun yang telah mahir mampu

merancang suatu website.

2. Multiplatform, yang berarti PHP dapat digunakan ke dalam berbagai platform $O S$

(Operating System) dan hampir semua browser juga mendukung $P H P$.

3. Free atau gratis, bersifat open source.

4. PHP memiliki tingkat akses yang cepat.

5. Didukung oleh beberapa macam web server.

6. Mendukung berbagai macam database. 


\subsubsection{Cara Kerja PHP}

"PHP merupakan bahasa Server Side Scripring, di mana PHP selalu membutuhkan we 國 Server: localhost 留 Database: dbupi pri

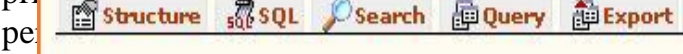
Client tersebut akan dikırımkan ke server, kemudian server akan mengembalikan pada halaman sesuai instruksi yang diminta" (Saputra, 2012). Berikut uraian dari penjelasan di atas

1. Server membaca permintaan dari client/ browser.

2. Kemudian dilanjutkan untuk mencari halaman/ page pada server.

3. Server melakukan instruksi yang diberikan oleh PHP untuk melakukan modifikasi pada halaman/ page.

Selanjutnya hasil modifikasi tersebut akan dikembalikan kepada client/browser.

\subsection{Grafik User Interface (GUI) MySQL Dengan Aplikasi XAMPP}

1. Membuat Database di MySQL

Database MySQL berikut ini dibuat dengan program Xamp, jika menggunakan program MySQL lainya pada umumnya hampir sama, perbedaan hanya pada posisi dan tampilanya saja. Maka untuk program selain Xampp disesuaikan.

a) Jalankan program Apache dan MySQlnya.

b) Buka internet explorer atau program browser lainnya.

c) Ketik di alamatnya / address : http://localhost/phpmyadmin/.

d) Buat nama database di create new database, lalu klik tombol create .

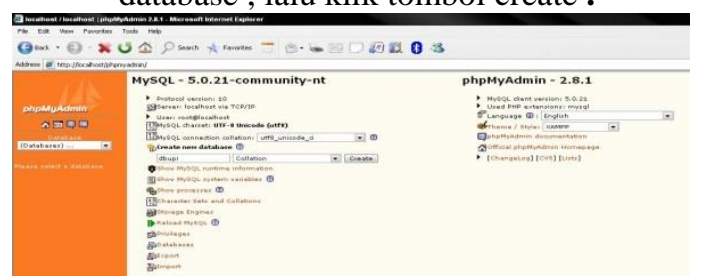

Gambar 2.6 Create Database Pada MySQL XAMPP

Ada beberapa Tab yang ada pada MySQL Xampp.

\section{Gambar 2.7 Tab Pada MySQL XAMPP}

a. Strukture

Pada tab ini terdapat table yang telah dibuat pada database, dan tempat untuk membuat table baru.

b. SQL

Pada tab SQL, terdapat tempat untuk memasukkan program SQL.

c. Search

Fungsi Search adalah tempat mencari data yang sudah pernah disimpan dalam table atau database.

$$
\text { d. Query }
$$

$\ldots \ldots$ b $\ldots$ base

7.

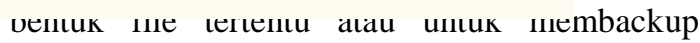
database.

b) Import

Memanggil database yang pernah disimpan untuk dimasukkan kedalam database mysql yang diinginkan.

\section{c) Operations}

Pada tab operation terdapat beberapa operasi yang dapat dilakukan pada database seperti : membuat table baru, membuat comment database, mengganti nama database, dan mengcopy database.

d) Privileges

Tempat informasi user yang dapat mengakses database.

e) Drop

Tab untuk menghapus database yang ada.

Ada tiga cara untuk membuat table di MySQL XAMPP, antara lain :

a) Membuat tanpa program MySQL

- Klik pada tab struktur.

- Buat nama table yang akan anda buat pada name di create new table on database, dan jumlah kolom pada table tersebut di number of fields, dan klik tombol go.

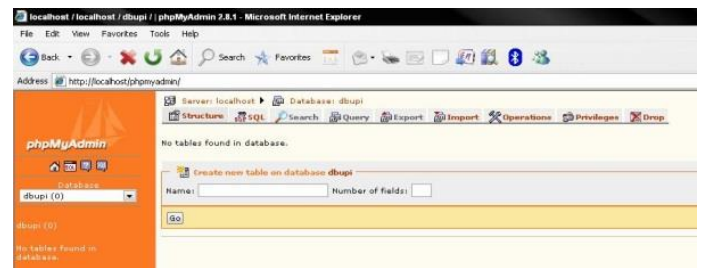

Gambar 2.8 Membuat Table Tanpa Program $M y S Q L$

- Buat nama masing-masing field / kolom dari table yang akan dibuat, dikolom field. Pilih Tipe dari field tersebut di type, isi panjang karakter di Length/values (kecuali date, datetime, time).

- Pilih option primary key jika field tersebut primary.

Klik tombol save untuk menyimpan

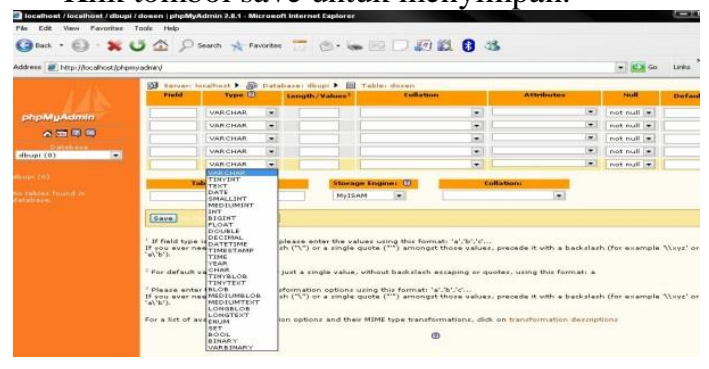




\section{Gambar 2.9 Mengisi Field Pada Table}

- Jika akan menambah field, maka isikan banyak field yang akan ditambah pada kolom Add, pilih posisinya dimana (diakhir table, diawal table atau setelah field tertentu). Dan klik tombol go.

b) Membuat dengan program MySQL

- Pilih tab SQL.

- ketik program MySQL ditempat Run SQL query/queries on database dan klik tombol go.

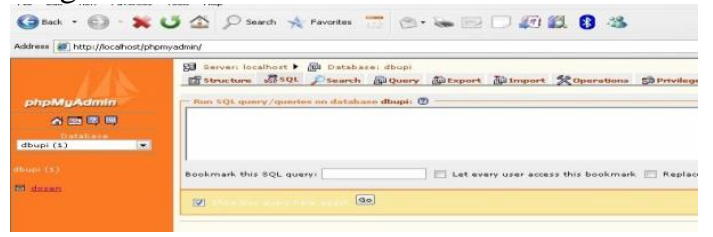

Gambar 2.9 Membuat Table Dengan Program MySQL

c) Membuat table MySQL dengan file yang telah disimpan sebelumnya, dibuat di notepad atau dibuat dengan program lainnya

- Pilih tab Import.

- Klik tombol

Browse kemudian pilih file yang disimpan tersebut.

- Klik tombol go.

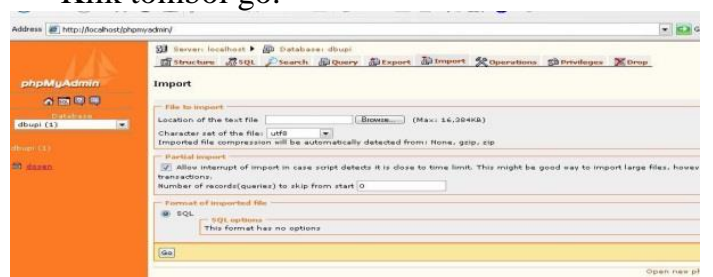

Gambar 2.10 Membuat Table Dengan File Yang Telah Disimpan Sebelumnya

e) Menyimpan Database MySQL.

Database yang telah dibuat di MySQL sesuai dengan cara yang diatas, sebenarnya sudah tersimpan tempat lain perlu dilakukan backup database. Adapun caranya sebagai berikut :

a) Pilih tab Export maka akan tampil form export seperti berikut :

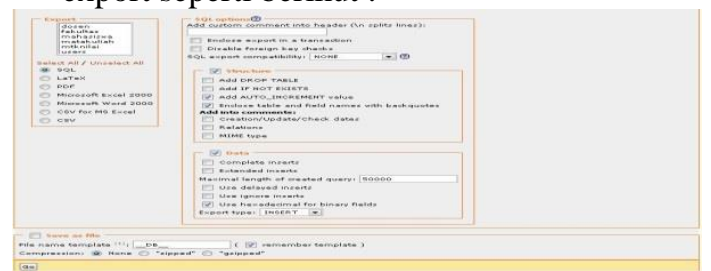

Gambar 2.11 Menyimpan Database MySQL

- Pilih bentuk file yang akan disimpan seperti SQL, Latex, pdf, dll (agar dapat diImport lagi pada Mysql sebaiknya pilih SQL).

- Check list pada struktur dan pada data sesuai yang ingin disimpan (jika ingin sama persis dengan yang aslinya check list semuanya pada struktur dan data.
- Check list save as file dan masukkan nama file pada file name template.

- Klik tombol go.

\subsection{Sekilas Tentang Dreamweaver}

Dreamweaver merupakan perangkat

lunak yang ditujukan untuk membuat suatu situs web. Versi pertama dirilis pada tahun 1997, dan sejak itu Dreamweaver menjadi web editor yang banyak digunakan oleh para web developer. Hal itu antara lain karena kemudahan dalam penggunaannya, kelengkapan fiturnya dan juga dukungannya terhadap teknologi terkini. Dreamweaver merupakan salah satu perangkat lunak yang dikembangkan oleh Macromedia Inc . Dan sekarang resmi Milik Adobe.

Setelah Dreamweaver terinstall di komputer, kita dapat mengaksesnya di menu Program Files. Untuk membukanya kita dapat membuka dengan memilih menu Start > All Programs $>$ Macromedia $>$ Macromedia Dreamweaver 8. Maka akan terbuka window start-up Dreamweaver

Dari window start-up Dreamweaver, terlihat 3 (tiga) kolom, yaitu Open a Recent Item, Create New dan Create From Samples. Pada kolom Open a Recent Item ditampilkan file-file yang terakhir dibuka (recent files). Kita dapat membuka file tersebut dengan mengklik salah satu nama file. Dan pada kolom ini juga terdapat menu Open yang dapat dipilih jika ingin membuka file atau dokumen yang belum ada di recent item.

Selanjutnya pada kolom Create New terdapat pilihan untuk membuat file baru. Pilihan file baru yang dapat dibuat dengan Dreamweaver antara lain file HTML, ColdFusion, PHP, ASP VBScript, Javascript, XML, CSS dan Dreamweaver Site. Pada kolom ketiga terdapat kategori Create From Samples dimana dapat kita pilih jika ingin membuat halaman web berdasarkan tampilan (template) yang sudah tersedia. Jadi pilihan ini dapat digunakan jika menginginkan membuat halaman web dengan cepat dan mudah.

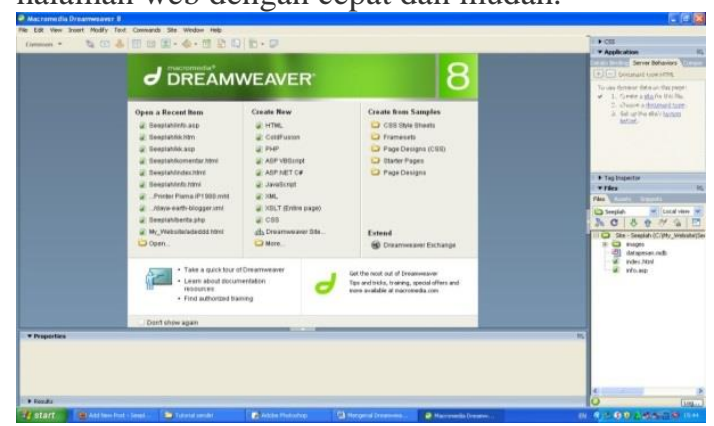

Sumber :

http://faltines.blogspot.com/2012/03/sekilasdreamweaver.html 
Gambar 2.12 Halaman Awal Dreamweaver 8 Pada halaman awal Dreamweaver 8 terdapat beberapa menu yang dapat dipilih, yaitu

\section{Open a Recent Item}

Pada menu ini akan ditampilkan beberapa file yang sebelumnya pernah kita buka dengan menggunakan Dreamweaver 8. Atau di paling bawah ada Open yang dapat digunakan untuk membuka file yang lain.

\section{Create New}

Pada menu ini kita dapat memilih dokumen baru apa yang akan kita buat dengan menggunakan Dreamweaver 8. Ada banyak pilihan, diantaranya HTML, ColdFusion, PHP, ASP, JavaScript, CSS.

\section{Create From Samples}

Pada menu ini kita dapat membuat file berdasarkan contoh yang sudah diberikan oleh Dreamweaver.

\section{$2.8 \quad M y S Q L$}

MySQL adalah salah satu jenis database server yang sangat dikenal dan digunakan unutk membangun aplikasi web yang menggunakan database sebagai sumber adn pengilahan data. MySQL juga besifat opensource dan mudah digunakan .(m.rudyanto arif, 2011) Karena komputer sangat unggul dalam menangani sejumlah besar data, sistem manajemen database (Database Management Systems/DBMS) memainkan suatu peran yang penting dalam komputasi, baik sebagai utilitas stand-alone maupun bagian dari aplikasi lainnya. MySQL adalah database server model relasional yang gratis di bawah lisensi GNU General Public License. Dengan sifatnya yang open source, memungkinkan user untuk melakukan modifikasi pada source code-nya untuk memenuhi kebutuhan spesifik mereka sendiri. MySQL merupakan database server multiuser dan multi-threaded yang tangguh (robust).

\subsection{UML (Unified Modelling Language)}

"Unified Modeling Language (UML) adalah salah satu alat bantu yang sangat handal didunia pengembangan sistem yang berorientasi objek" (Munawar, 2005). Hal ini disebabkan karena UML menyediakan bahasa pemodelan visual yang memungkinkan bagi pengembang sistem untuk membuat cetak biru atas visi mereka dalam bentuk yang baku, mudah dimengerti serta dilengkapi dengan mekanisme yang efektif untuk berbagi (sharing) dan mengkomunikasikan rancangan mereka dengan yang lain.

$U M L$ tidak hanya merupakan sebuah bahasa pemograman visual saja, namun juga dapat secara langsung dihubungkan ke berbagai bahasa pemograman, seperti JAVA, $C++$, Visual Basic, atau bahkan dihubungkan secara langsung ke dalam sebuah object-oriented database.

\subsubsection{Use Case Diagram.}

"Use Case adalah deskripsi fungsi dari sebuah sistem dari prespektif pengguna" (Munawar, 2005). Use Case bekerja dengan cara mendeskripsikan tipikal interaksi antara user (pengguna) sebuah sistem dengan sistemnya sendiri melalui sebuah cerita bagaimana sebuah sistem dipakai. Urutan langkah-langkah yang menerangkan antara pengguna dan sistem disebut Scenario. Setiap Scenario mendeskripsikan urutan kejadian. Setiap urutan diinisialisasi oleh orang, sistem yang lain, perangkat keras atau urutan waktu. Dengan demikian secara singkat bisa dikatakan use case adalah serangkaian scenario yang digabungkan bersama-sama oleh tujuan umum pengguna.

"Model use case adalah bagian dari model requirement” (Munawar, 2005). Termasuk disini adalah problem domain object dan penjelasan tentang user interface. Use case memberikan spesifikasi fungsi-fungsi yang ditawarkan oleh sistem dari prespektif user.

Setiap langkah dalam use case adalah sebuah elemen dalam interaksi antara actor dan sistem. Setiap langkah harus berupa pernyataan sederhana dan dengan jelas menunjukkan siapa yang menjalankan langkah tersebut. Langkah tersebut harus menunjukkan tujuan actor, bukan mekanisme yang harus dilakukan actor. Use case diagram menunjukkan 3 aspek dari sistem yaitu aktor, use case dan system atau sub system boundary. "Aktor mewakili peran orang, system yang lain atau alat ketika berkomunikasi dengan use case. Use case adalah abstraksi dari interaksi antara system dan aktor" (Munawar, 2005)

\subsubsection{Sequence Diagram}

Sequence diagram menggambarkan interaksi antar objek di dalam dan di sekitar sisem (termasuk pengguna, display, dan sebagainya) berupa message yang digambarkan terhadap waktu. Sequence diagram digunakan untuk menggambarkan perilaku pada sebuah scenario.

"Simbol-simbol yang ada pada sequence diagram” (Munawar, 2005) adalah:
1. Obyek atau 1
Sumber: Munaw
Gambar 2.... .........nnt pada sebuah
Sequence Diagram 
Obyek diletakkan di dekat bagian atas diagram dengan urutan dari kiri ke kanan. Setiap participant terhubung dengan garis titik-titik yang disebut lifeline. Sepanjang lifeline ada kotak yang disebut activation. Activation mewakili sebuah eksekusi operasi dari partcipant.

\section{Message}

Sebuah message bergerak dari satu participant ke participant yang lain dan dari satu lifeline ke lifeline yang lain. Sebuah message bisa jadi simple, synchronous atau asynchronous. Message yang simple adalah sebuah perpindahan (transfer) control dari satu participant ke participant yang lainnya. Jika sebuah participant mengirimkan sebuah message synchronous, maka jawaban atas message tersebut akan ditunggu sebelum diproses dengan urusannya. Namun jika message asynchronous yang akan dikirimkan, maka jawaban atas message tersebut tidak perlu ditunggu.

\subsubsection{Collaboration Diagram}

"Collabration diagram adalah perluasan dari obyek diagram (Obyek diagram menunjukkan obyek-obyek hubungannya satu dengan yang lain)” (Munawar, 2005). Collaboration diagram menunjukkan messagemessage obyek yang dikirimkan satu sama lain. Collaboration diagram adalah bentuk lain dari squence diagram. Bila squence diagram diorganisir menurut waktu maka collabration diagram diorganisir menurut ruang/ space.

Collaboration diagram merupakan asosiasi diantara obyek-obyek. Panah didekat garis asosiasi menunjukkan message, sedangkan content message ditunjukkan dengan label. Angka pada message menunjukkan urutan message. Collaboration diagram memungkinkan untuk memodelkan pengiriman sebuah message kebanyak obyek pada class yang sama. "Demikian juga hanya untuk

menunjukkan adanya obyek aktif yang mengendalikan aliran dari message" (Munawar, 2005).

\subsection{LUPUS ERITMATOSUS SISTEM (LES)}

2.10.1. Pengertian Lupus Eitmatosus Sistem (LES)

Lupus eritematosus sistemik (LES) adalah penyakit autoimun sistemik yang ditandai dengan adanya autoantibodi terhadap autoantigen, pembentukan kompleks imun, dan disregulasi sistem imun, menyebabkan kerusakan pada beberapa organ tubuh.

\subsubsection{Etiologi}

Faktor Resiko terjadinya SLE di antaranya yaitu :

1. Faktor Genetik

a. Jenis kelamin, frekuensi pada wanita dewasa 8 kali lebih sering dari pada pria dewasa.

b. Umur, biasanya lebih sering terjadi pada usia 20-40 tahun Etnik, Faktor keturunan, dengan Frekuensi 20 kali lebih sering dalam keluarga yang terdapat anggota dengan penyakit tersebut.

2. Faktor Resiko Hormon

Hormon estrogen menambah resiko SLE, sedangkan androgen mengurangi resiko ini.

\section{Sinar UV}

Sinar Ultra violet mengurangi supresi imun sehingga terapimenjadi kurang efektif, sehingga SLE kambuh atau bertambahberat. Ini disebabkan sel kulit mengeluarkan sitokin danprostaglandin sehingga terjadi inflamasi di tempat tersebut maupunsecara sistemik melalui peredaran pebuluh darah

4. Imunitas

Pada pasien SLE, terdapat hiperaktivitas sel B atau intoleransi terhadap sel T

5. Obat

Obat tertentu dalam presentase kecil sekali pada pasien tertentudan diminum dalam jangka waktu tertentu dapat mencetuskanlupus obat (Drug Induced Lupus Erythematosus atau DILE). Jenisobat yang dapat menyebabkan Lupus Obat adalah :

a. Obat yang pasti menyebabkan Lupus obat : Kloropromazin, metildopa, hidralasin, prokainamid, dan isoniazid.

b. Obat yang mungkin menyebabkan Lupus obat : dilantin, penisilamin, dan kuinidin. Hubungannya belum jelas : garam emas, beberapa jenis antibiotic dan griseofurvin

6. Infeksi

Pasien SLE cenderung mudah mendapat infeksi dan kadang- kadang penyakit ini kambuh setelah infeksi

7. Stres

Stres berat dapat mencetuskan SLE pada pasien yang sudah memiliki kecendrungan akan penyakit ini.

\subsubsection{Gejala Penyakit Lupus}

Gejala-gejala penyakit dikenal sebagai Lupus Eritomatosus Sistemik (LES) alias Lupus. Eritomatosus artinya kemerahan. sedangkan sistemik bermakna menyebar luas keberbagai organ tubuh. Istilahnya disebut LES atau Lupus. Gejala-gejala yang umum dijumpai adalah. 
1. Kulit yang mudah gosong akibat sinar matahari serta timbulnya gangguan pencernaan.

2. Gejala umumnya penderita sering merasa lemah, kelelahan yang berlebihan, demam dan pegal-pegal. Gejala ini terutama didapatkan pada masa aktif, sedangkan pada masa remisi (nonaktif) menghilang.

3. Pada kulit, akan muncul ruam merah yang membentang di kedua pipi, mirip kupukupu. Kadang disebut (butterfly rash). Namun ruam merah menyerupai cakram bisa muncul di kulit seluruh tubuh, menonjol dan kadang-kadang bersisik Melihat banyaknya gejala penyakit ini, maka wanita yang sudah terserang dua atau lebih gejala saja, harus dicurigai mengidap Lupus.

4. Anemia yang diakibatkan oleh sel-sel darah merah yang dihancurkan oleh penyakit LUPUS ini

5. Rambut yang sering rontok dan rasa lelah yang berlebihan

Contoh Penderita Penyakit Lupus Eritmatosus

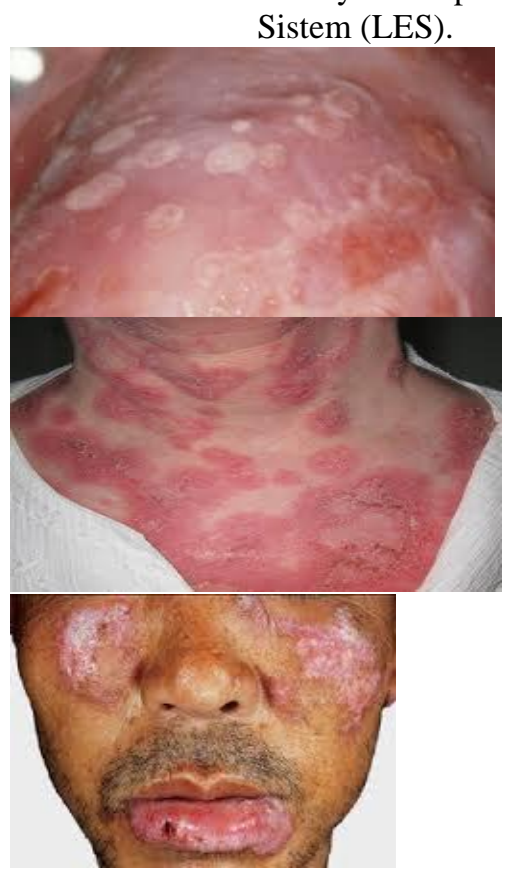

Gambar 2.17 Penyakit Lupus

\subsubsection{Klasifikasi Lupus}

Penyakit Lupus dapat diklasifikasikan menjadi 3 macam yaitu discoid lupus, Systemic Lupus Erythematosus, dan lupus yang diinduksi oleh obat.

\section{Discoid Lupus}

Lesi berbentuk lingkaran atau cakram dan ditandai oleh batas eritema yang meninggi, skuama, sumbatan folikuler, dan telangiektasia. Lesi ini timbul di kulit kepala, telinga, wajah, lengan, punggung, dan dada.
Penyakit ini dapat menimbulkan kecacatan karena lesi ini memperlihatkan atrofi dan jaringan parut di bagian tengahnya serta hilang nya apendiks kulit secara menetap (Hahn, 2005).

2. Systemic Lupus Erythematosus

SLE merupakan penyakit radang atau inflamasi multisistem yang disebabkan oleh banyak faktor (Isenberg and Horsfall,1998) dan dikarakterisasi oleh adanya gangguandisregulasi sistem imun berupa peningkatan sistem imun dan produksi autoantibodi yang berlebihan (Albar, 2003). Terbentuknya autoantibodi terhadap dsDNA, berbagai macam ribonukleoprotein intraseluler, sel-sel darah, dan fosfolipid dapat menyebabkan kerusakan jaringan (Albar, 2003) melalui mekanime pengaktivan komplemen (Epstein, 1998).

3. Lupus yang diinduksi oleh obat

Lupus yang disebabkan oleh induksi obat tertentu khususnya pada asetilator lambat yang mempunyai gen HLA DR-4 menyebabkan asetilasi obat menjadi lambat, obat banyak terakumulasi di tubuh sehingga memberikan kesempatan obat untuk berikatan dengan protein tubuh. Hal ini direspon sebagai benda asing oleh tubuh sehingga tubuh membentuk kompleks antibodi antinuklear (ANA) untuk menyerang benda asing tersebut (Herfindal et al. 2000).

\subsubsection{Patofisiologi}

Penyakit SLE terjadi akibat terganggunya regulasi kekebalan yang menyebabkan

Peningkatan autoantibodi yang berlebihan. Gangguan imunoregulasi ini ditimbulkan oleh kombinasi antara faktor-faktor genetik, hormonal ( sebagaimana terbukti oleh awitan penyakit yang biasanya terjadi selama usia reproduktif) dan lingkungan (cahaya matahari,luka bakar termal). Obat-obat tertentu seperti hidralazin, prokainamid, isoniazid, klorpromazin dan beberapa preparat antikonvulsan di samping makanan seperti kecambah alfalfa turut terlibat dalam penyakit SLE- akibat senyawa kimia atau obat-obatan.

Pada SLE, peningkatan produksi autoantibodi diperkirakan terjadi akibat fungsi sel $\mathrm{T}$ supresor yang abnormal sehingga timbul penumpukan kompleks imun dan kerusakan jaringan. Inflamasi akan menstimulasi antigen yang selanjutnya serangsang antibody tambahan dan siklus tersebut berulang kembali.

\subsubsection{Kriteria SLE}

Pada tahun 1982, American Rheumatism Association (ARA) menetapkan kriteria baru untuk klasifikasi SLE yang 
diperbarui pada tahun 1997. Kriteria SLE ini mempunyai selektivitas 96\%. Diagnosa SLE dapat ditegakkan jika pada suatu periode pengamatan ditemukan 4 atau lebih kriteria dari 11 kriteria yaitu :

1. Artritis, arthritis nonerosif pada dua atau lebih sendi perifer disertai rasa nyeri, bengkak, atau efusi dimana tulang di sekitar persendiantidak mengalami kerusakan

2. Tes ANA diatas titer normal = Jumlah ANA yang abnormalditemukan dengan immunofluoroscence atau pemeriksaan serupajika diketahui tidak ada pemberian obat yang dapat memicu ANAsebelumnya

3. Bercak Malar / Malar Rash (Butterfly rash) = Adanya eritemaberbatas tegas, datar, atau berelevasi pada wilayah pipi sekitarhidung (wilayah malar)

4. Fotosensitif bercak reaksi sinar matahari = peka terhadap sinar UV /matahari, menyebabkan pembentukan atau semakin memburuknyaruam kulit

5. Bercak diskoid = Ruam pada kulit

6. Salah satu Kelainan darah;
a) anemia hemolitik,
b) Leukosit $<4000 / \mathrm{mm}^{3}$,
c) Limfosit $<1500 / \mathrm{mm}^{3}$,
d) Trombosit $<100.000 / \mathrm{mm}^{3}$

7. Salah satu Kelainan Ginjal;
a) Proteinuria $>0,5 \mathrm{~g} / 24 \mathrm{jam}$,
b) Sedimen seluler = adanya elemen abnormal dalam air kemih yang berasal dari sel darah merah/putih maupun sel tubulus ginjal

8. Salah satu Serositis :
a) Pleuritis,
b) Perikarditis

9. Salah satu kelainan Neurologis;
a) Konvulsi / kejang,
b) Psikosis

10. Ulser Mulut, Termasuk ulkus oral dan nasofaring yang dapatditemukan

11. Salah satu Kelainan Imunologi
a) Sel LE+
b) Anti dsDNA diatas titer normal
c) Anti Sm (Smith) diatas titer normal
d) Tes serologi sifilis positif palsu

\section{METODE PENELITIAN}

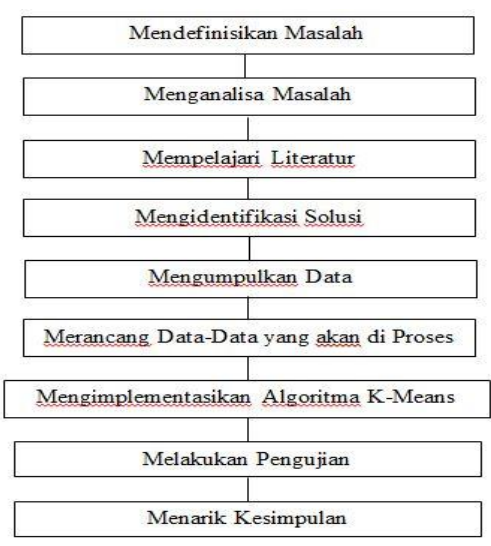

\section{HASIL DAN PEMBAHASAN}

\subsection{Analisa Data}

Dalam mengumpulkan data dilakukan dengan cara melakukam wawancara serta mengambil data kepada administrasi kantor tersebut. Faktor-faktor yang mempengaruhi gaji karyawan banyak jenisnya, diantaranya faktor Intern dan faktor Ekstern. Namun pada penelitian ini faktor yang digunakan adalah faktor Intern. Faktor-faktor ini nantinya akan dikelompokkan sehingga membantu dalam memahami data gaji karyawan. Penganalisaan dilakukan berdasarkan fakta dan data yang didapat di PT Indomex Dwijaya Lestari.

\subsection{Analisa Clustering dengan Menggunakan Algoritma K-Means}

Analisis cluster merupakan pengelompokan objek-objek data hanya berdasarkan pada informasi yang terdapat pada data, yang menjelaskan objek dan relasinya. Tahapan algoritma $K$-Means dapat dilihat pada gambar 4.1 : 


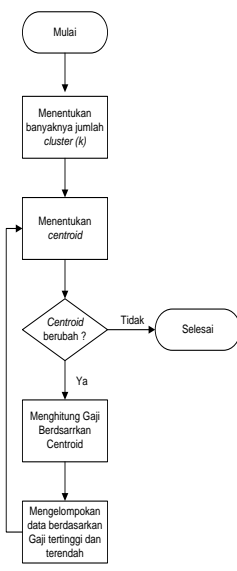

Gambar 4.1 : Diagram Proses Flowchart

\subsection{Penetapan Data \\ K-Means}

Sebelum melakukan proses pengelompokan data siswa, terlebih dahulu tentukan data yang akan dilakukan pengolahan agar tujuan penelitian dapat tercapai. Adapun langkah-langkahnya sebagai berikut :

\subsection{Menentukan Atribut Yang Digunakan}

Pada penelitian ini faktor yang mempengaruhi gaji karyawan tetap dan karyawan kontrak yaitu :

1. Bagian kerja karyawan

2. Status kerja karyawan

3. Gaji Pokok karyawan

4. Hari kerja karyawan

5. Total gaji karyawan

\subsection{Pengkodean Data}

Untuk membuktikan bahwa faktor rekap gaji karyawan dipengaruhi oleh faktor - faktor yang telah ditentukan seperti yang sudah dijelaskan sebelumnya maka dibutuhkan suatu alat bantu untuk membuktikannya yaitu berupa rekap gaji karyawan dengan melihat total gaji karyawan. Adapun data yang diolah yaitu karyawan tetap sebanyak 32 orang, sedangkan karyawan kontrak 28 orang, pada tabel berikut adalah data yang mewakili saja, terlihat pada tabel 4.1 :
Tabel 4.1: Sampel Data Karyawan

\begin{tabular}{|c|c|c|c|c|c|c|}
\hline No & Nama & Bagian & Status & Gaji Pokok & $\begin{array}{c}\text { Jumulab } \\
\text { Hani } \\
\text { Kerja }\end{array}$ & $\begin{array}{c}\text { Yang } \\
\text { Diterima }\end{array}$ \\
\hline 1 & $\begin{array}{l}\text { RUDI } \\
\text { DARMAWI }\end{array}$ & DIREXSI & TETAP & Bo $3,000,000$ & 25 & Bos $\quad 3,329,075$ \\
\hline 2 & $\begin{array}{l}\text { RIRO } \\
\text { MLAYER }\end{array}$ & $\begin{array}{l}\text { GENERAL } \\
\text { MGANAGER }\end{array}$ & TETAP & Bs. $2,590,000$ & $2 s$ & Bs. $3,1000,675$ \\
\hline \begin{tabular}{|l|}
3 \\
4
\end{tabular} & $\begin{array}{l}\text { MAAWARDI } \\
\text { MASLAN }\end{array}$ & $\begin{array}{l}\text { 3ERKANIK } \\
\text { MEKANIK }\end{array}$ & $\frac{\text { TETAP }}{\text { TETAP }}$ & 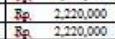 & $\frac{25}{25}$ & \begin{tabular}{|ll}
89 & $2,713,075$ \\
39 & $2,713,075$ \\
39
\end{tabular} \\
\hline 5 & MUULAIRI & $\begin{array}{l}\text { MaANGER } \\
\text { OP PRO }\end{array}$ & TETAP & If $2.300,000$ & 25 & sa 283509 \\
\hline 6 & MAWARDI $\mathrm{K}$ & $\begin{array}{l}\text { W KANAGER } \\
\text { ANDK }\end{array}$ & TETAP & Bo. $2,300,000$ & 25 & \begin{tabular}{|ll}
8 & 2.8150075 \\
\end{tabular} \\
\hline 7 & $\begin{array}{l}\text { AZHARI } \\
\text { AGUSTI }\end{array}$ & \begin{tabular}{|l} 
MGANAGER \\
AKUNTANSI \\
\end{tabular} & TETAP & Is $\quad 2,300,000$ & 25 & Bs $\quad 28150075$ \\
\hline 8 & JuIANO & $\begin{array}{l}\text { MANAAGER } \\
\text { PEMASARAN } \\
\end{array}$ & TETAP & F $F_{q} \quad 2,300,000$ & 25 & Bo $\quad 2,815,075$ \\
\hline 9 & $\begin{array}{l}\text { GEETIANI } \\
\text { BUULOLIO }\end{array}$ & $\begin{array}{l}\text { PERSONALIA } \\
\text { DAN UMUMA }\end{array}$ & TETAP & Bs $\quad 2,300,000$ & 25 & Bgs $\quad 2,815,075$ \\
\hline 10 & SAROEWI & $\begin{array}{l}\text { PRODUUKSI II } \\
\text { PLAST }\end{array}$ & TETAP & Bo. $\quad 2,300,000$ & $2 s$ & Bs 2.815.07s \\
\hline 11 & ANDHIKA & $\begin{array}{l}\text { PENGAWAS } \\
\text { PRODUKSI }\end{array}$ & TETAP & Bs. $2,300,000$ & 25 & Bs $2,515,075$ \\
\hline 12 & YoLA & $\begin{array}{l}\text { ADMG } \\
\text { PEMELLIAN }\end{array}$ & TETAP & $B_{s} \quad 2,050,000$ & 20 & 39. 2560,075 \\
\hline 13 & MERT & $\begin{array}{l}\text { ADMG } \\
\text { PENUALAN }\end{array}$ & TETAP & Bs. 2050,000 & 20 & Bs $2.560,075$ \\
\hline 14 & RMA & $\begin{array}{l}\text { ADDM } \\
\text { PENUALAN }\end{array}$ & TETAP & s.s. 2, 050,000 & 20 & Fis $2,560,075$ \\
\hline 15 & WULAN & $\begin{array}{l}\text { ADMG } \\
\text { PENUALAN }\end{array}$ & IETAP & Bs $\quad 2,050,000$ & 20 & B. $2,560,075$ \\
\hline 16 & \begin{tabular}{|l|l|} 
FAUZII \\
BSYI
\end{tabular} & SDM & TETAP & $\begin{array}{ll}39 & 2,050,000 \\
399 & 0\end{array}$ & 25 & $\begin{array}{ll}3.5450,075 \\
39\end{array}$ \\
\hline 17 & $\begin{array}{l}\text { RNAA } \\
\text { SIALANGAN }\end{array}$ & KASIR & TETAP & Bp 2050,000 & 25 & Isq. $2: 250,075$ \\
\hline 18 & $\begin{array}{l}\text { MEST } \\
\text { ROSWITA }\end{array}$ & ADM BANK & TETAP & Bg, $2,050,000$ & 25 & Bh $2,560,075$ \\
\hline 19 & FEROLANTO & GUDANG & TETAP & Bs $20,050,000$ & 25 & $\begin{array}{ll}3.560,075 \\
39\end{array}$ \\
\hline 20 & MGASASRIL & $\begin{array}{l}\text { RAAGDDANG } \\
\text { BARANG } \\
\text { IADI } \\
\end{array}$ & TETAP & Bs. $\quad 2,014,000$ & $2 s$ & Bs. $2.523,395$ \\
\hline 21 & VIARAZ & $\begin{array}{l}\text { ADM } \\
\text { PIUTANG }\end{array}$ & TETAP & Bs $\quad 2,050,000$ & 25 & S.s. $2.560,075$ \\
\hline 22 & RETHA & \begin{tabular}{|l|} 
ADM \\
GUDANG \\
\end{tabular} & IETAP & BS. $2,050,000$ & 25 & 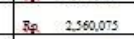 \\
\hline 23 & OKY & $\begin{array}{l}\text { ADM } \\
\text { GUDANG }\end{array}$ & TETAP & Bf 2050,000 & $2 s$ & $F_{80} \quad 2560.075$ \\
\hline \begin{tabular}{|l|}
24 \\
\end{tabular} & WANDI & \begin{tabular}{|l|l|} 
SATPANS \\
\end{tabular} & TETAP & 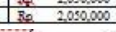 & 25 & 189.2560 .075 \\
\hline No & Sama & Bagian & Status & Gaji Rolkolk & $\begin{array}{c}\text { Jumlah } \\
\text { Hari } \\
\text { Kerja }\end{array}$ & Yang Diterima \\
\hline$\frac{25}{38}$ & \begin{tabular}{|l|l|} 
DOODI \\
0000
\end{tabular} & SATPAS & $\begin{array}{l}\text { TETAP } \\
\text { TETS }\end{array}$ & \begin{tabular}{|ll}
$8,0,050,000$ \\
8
\end{tabular} & 23 & 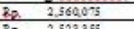 \\
\hline$\frac{26}{27}$ & $\begin{array}{l}\text { OYONG } \\
\text { R1CKR] }\end{array}$ & $\begin{array}{l}\text { DRNER } \\
\text { DRNER }\end{array}$ & $\begin{array}{l}\text { TETAS } \\
\text { TEIAP }\end{array}$ & $\begin{array}{ll}\frac{B a}{B_{2}} & 2,014000 \\
g_{2}, 014000\end{array}$ & $\frac{20}{20}$ & 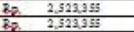 \\
\hline 28 & RLDSDS & DRAER & TETAP & 892,0440000 & 20 & $\begin{array}{ll}2.5223 .955 \\
89\end{array}$ \\
\hline$\frac{29}{30}$ & \begin{tabular}{|l|} 
2UARVAT \\
DEFIS \\
\end{tabular} & $\begin{array}{l}\text { DRERER } \\
\text { DRNER }\end{array}$ & $\frac{\text { TENA }}{\text { TENAP }}$ & 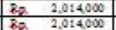 & $\frac{20}{20}$ & 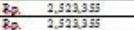 \\
\hline 31 & \begin{tabular}{|l|} 
RLSDI \\
\end{tabular} & DRIVER & TETAP & $\begin{array}{ll}0.040000 \\
89 & 2,044000\end{array}$ & 20 & 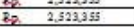 \\
\hline$\frac{32}{33}$ & 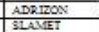 & 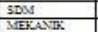 & $\frac{\text { TEIAS }}{\text { TEOTSRAK }}$ & $\begin{array}{ll}89 & 2,0140000 \\
89 & 1,000725 \\
\end{array}$ & $\frac{20}{23}$ & 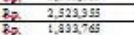 \\
\hline 34 & DUTRA & DRNER & BonThutK & $\begin{array}{ll}28 \\
89 & 1.900725 \\
\end{array}$ & 20 & 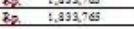 \\
\hline 35 & BADI & $\begin{array}{l}\text { ANosta } \\
\text { GLANG }\end{array}$ & кostaak: & $B \quad 1,000725$ & 20 & Ba. $\quad:, 839766$ \\
\hline 36 & viraa & $\begin{array}{l}\text { ANOSOTA } \\
\text { GDDNOE }\end{array}$ & MONTRuK & $\mathrm{Bg} \quad \mathrm{i}, 900725$ & 20 & Ba $\quad 1,993,765$ \\
\hline 37 & WLARS & $\begin{array}{l}\text { ANGOSTA } \\
\text { GLDANG }\end{array}$ & ronthax & $\mathrm{Bg} \quad 1,900725$ & 20 & Bo $\quad 1,931765$ \\
\hline$\frac{38}{39}$ & \begin{tabular}{|l|l|}
521 \\
20191
\end{tabular} & \begin{tabular}{|l|} 
SALES \\
SMARE
\end{tabular} & 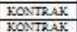 & $\begin{array}{ll}89 & t, 300,25 \\
80 & :, 900225\end{array}$ & $\frac{18}{13}$ & 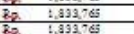 \\
\hline 40 & KEVDRA & 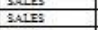 & 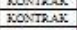 & $\begin{array}{ll}\mathrm{kg} \\
\mathrm{kg} & 1.800725\end{array}$ & $\frac{18}{18}$ & 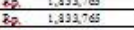 \\
\hline$\frac{41}{48}$ & $\begin{array}{l}\text { Yon } \\
\end{array}$ & $\begin{array}{l}\text { SALES } \\
\text { SATPAYM }\end{array}$ & RONTRAK: & \begin{tabular}{|ll}
8000725 \\
8
\end{tabular} & 18 & 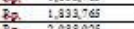 \\
\hline$\frac{42}{43}$ & Chas & 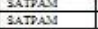 & 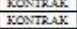 & 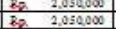 & $\frac{25}{25}$ & 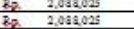 \\
\hline 44 & $A R I T$ & BOLLER & 300sthat: & 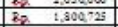 & 20 & 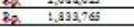 \\
\hline & & & & & & $89 \quad 1,932,765$ \\
\hline 45 & Shons & FORNSLA & KONTRAK & \begin{tabular}{|ll}
$\mathrm{Bg}$ & $:, 800725$ \\
\end{tabular} & 20 & $\begin{array}{ll}80 & 1,992765 \\
8\end{array}$ \\
\hline$\frac{47}{45}$ & 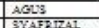 & 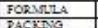 & 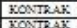 & 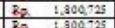 & 20 & 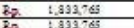 \\
\hline$\frac{73}{49}$ & 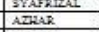 & & & 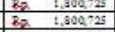 & 20 & 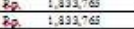 \\
\hline & vasa & PACKNO & KONTRAK & \begin{tabular}{|ll}
$\operatorname{Bg}$ & 1,000725 \\
\end{tabular} & 20 & $82 \quad 1.992706$ \\
\hline 11 & DISA & 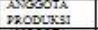 & BONTRAS: & Bg. 2, 2050,000 & 28 & $\mathrm{Bg} \quad 2,034025$ \\
\hline 52 & saska & 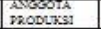 & BONTREKK & Bg. 2.050000 & $2 \mathrm{~s}$ & $\begin{array}{ll}38 & 2,034025\end{array}$ \\
\hline 53 & SeAvar. & $\begin{array}{l}\text { CLENG } \\
\text { SERVCE }\end{array}$ & HoNThuK & \begin{tabular}{|ll}
$\mathrm{Bg}$ & 1,000725 \\
\end{tabular} & 25 & Bg. $\quad$ :.992765 \\
\hline 54 & LASTRI & SERVAE & BONTRAK & $\mathrm{Bg} \quad \mathrm{t}, 000,725$ & is & Bg. $\quad:, 0939765$ \\
\hline 19 & JIERI & $\begin{array}{l}\text { CLEWKG } \\
\text { SERVIE }\end{array}$ & Bontrak & Bg. $\quad 1,0004725$ & 25 & Bg. $\quad 1,8997,65$ \\
\hline 56 & & $\begin{array}{l}\text { CIENAS } \\
\text { SERVICE }\end{array}$ & KONTRAS: & Bg $\quad 1,900,725$ & 25 & Ba. $\quad$ :.9921765 \\
\hline 57 & 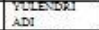 & SDM & TRAK & & 20 & $80 \quad 1.939765$ \\
\hline 38 & ADRIZON & & & 89.8000725 & 20 & $\begin{array}{ll}88 & 1.932765 \\
8\end{array}$ \\
\hline 59 & searsarr. & $\begin{array}{l}\text { BLRA } \\
\text { BARD } \\
\text { IADI }\end{array}$ & YONTRAK & $\mathrm{Ba} \quad 1,900725$ & 20 & B2. $\quad 1,939765$ \\
\hline 60 & & \begin{tabular}{|l} 
GLDANG \\
BARAVG
\end{tabular} & & & & \\
\hline
\end{tabular}

\subsection{Transformasi Data}

Transformasi data dilakukan karena jenis data tidak berupa numeric maka data harus ditranformasikan terlebih dahulu dengan cara melakukan frekuensi pada data yang terbanyak muncul dengan mengurutkan frekuensi tertinggi ke terendah dan lakukan inisial data. 


\subsection{Proses Clustering Menggunakan Algoritma K-Means}

Data yang sudah ditetapkan akan dilakukan pengolahan

Tabel 4.2: Sampel Data Siswa Proses Clustering

Tabel 4.7 Sampel Data Kansawan. Proses Clustering

\begin{tabular}{|c|c|c|c|c|c|c|}
\hline No & Nama & Bagian & Status & $\begin{array}{c}\text { Gaji } \\
\text { Polkok }\end{array}$ & $\begin{array}{c}\text { Jumlabh } \\
\text { Hari } \\
\text { Keria }\end{array}$ & $\begin{array}{c}\text { Yang } \\
\text { Diterima }\end{array}$ \\
\hline 1 & RUDIDARMANI & 1 & 1 & 1 & 1 & 3 \\
\hline 2 & RIKO NCAYER & 2 & 1 & 2 & 1 & 3 \\
\hline 3 & NAWARDI & 3 & 1 & 3 & 1 & 2 \\
\hline 4 & MASLAN & 3 & 1 & 3 & 1 & 2 \\
\hline 5 & MULFAIRI & 4 & 1 & 4 & 1 & 2 \\
\hline 6 & MAWARDIK & 5 & 1 & 4 & 1 & 2 \\
\hline$?$ & AZHARI AGUSTI & 6 & 1 & 4 & 1 & 2 \\
\hline 8 & JULIANO & 7 & 1 & 4 & 1 & 2 \\
\hline 9 & $\begin{array}{l}\text { GESTAANI } \\
\text { BUULOLO }\end{array}$ & 8 & 1 & 4 & 1 & 2 \\
\hline 10 & $\begin{array}{l}\text { BUULOLO } \\
\text { SARDEWI }\end{array}$ & 9 & $\frac{1}{1}$ & $\frac{7}{4}$ & $\frac{1}{1}$ & $\frac{4}{2}$ \\
\hline 11 & ANDHIKA & 10 & 1 & 4 & 1 & 2 \\
\hline 12 & YOLA & 11 & 1 & 5 & 2 & 2 \\
\hline 13 & MERI & 12 & 1 & 5 & 2 & 2 \\
\hline 14 & RMCA & 12 & 1 & 5 & 2 & 2 \\
\hline 15 & WULAN & 12 & 1 & 5 & 2 & 2 \\
\hline 16 & FAUZI & 13 & 1 & 5 & 1 & 2 \\
\hline 17 & RNAA & & & & & \\
\hline
\end{tabular}

data dengan proses clustering dengan menggunakan algoritma $K$-Means sehingga didapatkanlah hasil pengelompokan terbaik yang nantinya akan membantu dalam pemahaman data karyawan.

1. Penentuan jumlah cluster

Penentuan jumlah cluster dilakukan untuk mengetahui hasil dari total gaji karyawan. Maka dalam penelitian ini jumlah cluster yang digunakan adalah sebanyak 4 cluster $(k=4)$, sehingga nanti akan diketahui cluster terbaik dalam melakukan penelitian ini.

2. Menentukan centroid

Pusat awal cluster atau centroid ditentukan secara random atau acak, dimana nilai cluster 0 diambil dari baris ke-11, nilai cluster 1 pada baris ke-47. Berikut nilai titik pusat awal cluster (centroid) yang dapat dilihat pada tabel : 
masing cluster dengan cara

\begin{tabular}{|c|c|c|c|c|c|c|}
\hline NO & NAMA & BAGIAN & STATUS & $\begin{array}{c}\text { GAJI } \\
\text { POKOK }\end{array}$ & $\begin{array}{c}\text { JUMLAH } \\
\text { H.K }\end{array}$ & TOTAL \\
\hline 11 & ANDHIIA & 10 & 1 & 4 & 1 & 2 \\
\hline 47 & AGUS & 25 & 2 & 7 & 2 & 1 \\
\hline
\end{tabular}

mengelompokkan berdasarkan jarak minimum objek ke pusat cluster dengan memberikan kode "1" jika hasil cluster

Tabel 4.7 Titik Pusat Awal Cluster

Cluster $0:(11 ; 10 ; 1 ; 4 ; 1 ; 2)$

Cluster $1:(47 ; 25 ; 2 ; 7 ; 2 ; 1)$

3.Menghitung jarak dari centroid

Menghitung jarak antara titik centroid dengan titik tiap objek dengan menggunakan Euclidian Distance. Ada pun penghitungan centroid awal secara manual. Perhitungannya adalah sebagai berikut:

Perhitungan dengan rumus :

$$
D(i, j)=\sqrt{\left(X_{1 i}-X_{1 j}\right)^{2}+\left(X_{2 i}-X_{2 j}\right)^{2}+\cdots+\left(X_{k i}-X_{k j}\right)^{2}}
$$

Perhitungan jarak dari data ke-1 terhadap pusat cluster :

Centroid $1=$

Centroid2

$$
\sqrt{(1-10)^{2}+(1-1)^{2}+(1-4)^{2}+(1-1)^{2}+(2-2)^{2}}=90
$$

Centroid $3=$

$$
\sqrt{(2-10)^{2}+(1-1)^{2}+(2-4)^{2}+(1-1)^{2}+(3-2)^{2}}=69
$$

$$
\sqrt{(3-10)^{2}+(1-1)^{2}+(3-4)^{2}+(1-1)^{2}+(2-2)^{2}}=50
$$

Centroid $4=$

$$
\sqrt{(3-10)^{2}+(1-1)^{2}+(3-4)^{2}+(1-1)^{2}+(2-2)^{2}}=50
$$

Centroid 5=

$$
\sqrt{(4-10)^{2}+(1-1)^{2}+(4-4)^{2}+(1-1)^{2}+(2-2)^{2}}=36
$$

Perhitungan jarak dari data ke-2 terhadap pusat cluster :

Centroid $1=$

$$
\sqrt{(1-25)^{2}+(1-2)^{2}+(1-7)^{2}+(1-2)^{2}+(2-1)^{2}}=615
$$

Centroid $2=$

$$
\sqrt{(2-25)^{2}+(1-2)^{2}+(2-7)^{2}+(1-2)^{2}+(3-1)^{2}}=560
$$

Centroid $3=$

$$
\sqrt{(3-25)^{2}+(1-2)^{2}+(3-7)^{2}+(1-2)^{2}+(2-1)^{2}}=503
$$

Centroid4

$$
\sqrt{(3-25)^{2}+(1-2)^{2}+(3-7)^{2}+(1-2)^{2}+(2-1)^{2}}=503
$$

Centroid5=

$\sqrt{(4-25)^{2}+(1-2)^{2}+(4-7)^{2}+(1-2)^{2}+(2-1)^{2}}=453$

Alokasikan masing-masing objek ke centroid terdekat, untuk melakukan mengalokasikan objek ke dalam masing- mendekati nol. Perhitungan dilakukan terus sampai data ke-60 terhadap pusat cluster. Setelah dilakukan proses perhitungan maka akan didapatkan data seperti Tabel 4.3:

\section{Tabel 4.3 : Hasil Perhitungan Gaji dan} Pengelompokan Data Iterasi ke-1

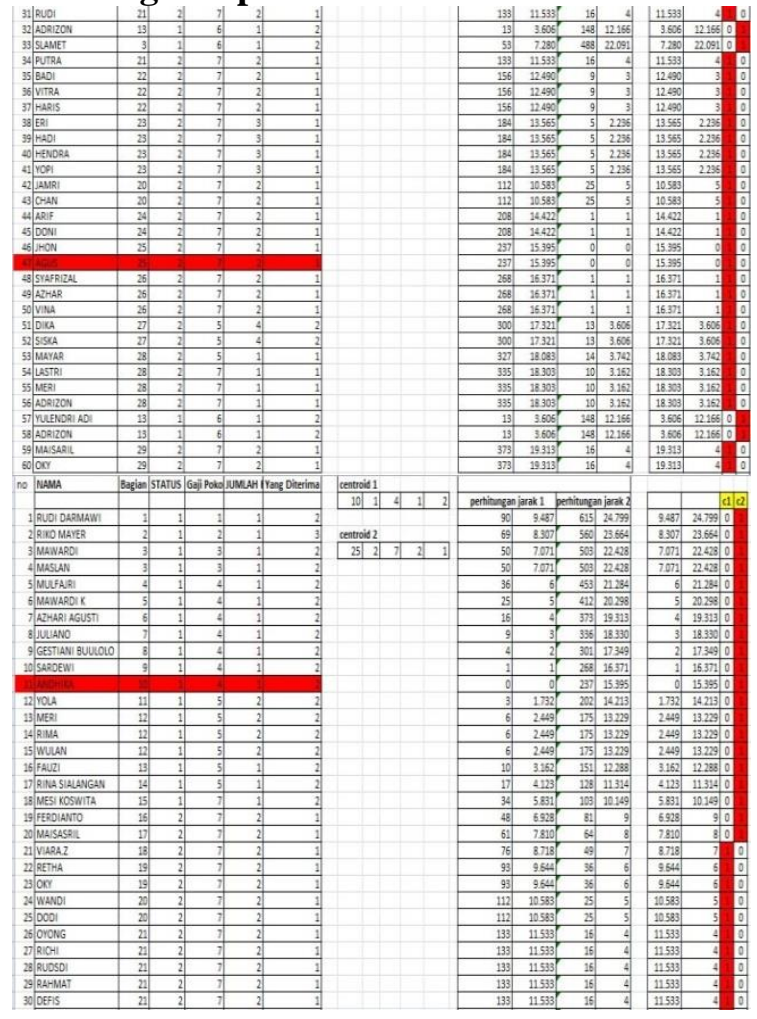

Setelah dilakukan iterasi ke-1 maka lakukan iterasi ke-2 untuk membandingkan letak posisi hasil cluster 1 dan cluster 2. Jika posisinya tidak berubah maka iterasi berikutnya tidak perlu dilakukan lagi. Untuk melakukan iterasi ke-2 maka tentukan cluster baru terlebih dahulu.

1. Melakukan Pencarian Iterasi 2

Pada pembahasan ini dilakukan pencarian iterasi 2, dengan melakukan perhitungan sebagai berikut : 


\begin{tabular}{|l|r|c|c|c|c|}
\hline Pusat cluster 1 & 23,361 & 2 & 6,833 & 2,111 & 1,056 \\
\hline Pusat cluster 2 & 9,25 & 1,083 & 4,667 & 1,25 & 1,958 \\
& & & & & \\
\hline
\end{tabular}

a. Perhitungan jarak data 1 terhadap pusat

cluster.

Perhitungan pusat cluster terhadap data 1 dengan penjelasan sebagai berikut:

$$
D\left(i, j=\sqrt{\left(X_{1 i}-X_{1 j}\right)^{2}+\left(X_{2 i}-X_{2 j}\right)^{2}+\cdots+\left(X_{k i}-X_{k j}\right)^{2}}\right.
$$

Perhitungan gaji dari data ke-1 terhadap pusat cluster :

Centroid $1=$

$\begin{array}{cc}\sqrt{(1-23,361)^{2}+(1-2)^{2}+(1-6,833)^{2}+(1-2,111)^{2}+(2-1,056)^{2}} \\ = & 537.174\end{array}$

Centroid $2=$

$\sqrt{(2-23,361)^{2}+(1-2)^{2}+(2-6,833)^{2}+(1-2,111)^{2}+(3-1,056)^{2}}$
$=\quad 485.674$

Centroid 3 =

$\sqrt{(3-23,361)^{2}+(1-2)^{2}+(3-6,833)^{2}+(1-2,111)^{2}+(2-1,056)^{2}}$
$=\quad 432.396$

Centroid 4 =

$\sqrt{(3-23,361)^{2}+(1-2)^{2}+(3-6,833)^{2}+(1-2,111)^{2}+(2-1,056)^{2}}$

Centroid $5=$

$\sqrt{(4-23,361)^{2}+(1-2)^{2}+(4-6,833)^{2}+(1-2,111)^{2}+(2-1,056)^{2}}$
$=\quad 386.007$

Perhitungan gaji dari data ke-2 terhadap pusat cluster :

Centroid $1=$

$\sqrt{(1-9,25)^{2}+(1-1,083)^{2}+(1-4,667)^{2}+(1-1,125)^{2}+(2-1,958)^{2}}$ 81,578

Centroid $2=$

$\sqrt{(2-9,25)^{2}+(1-1,083)^{2}+(2-4,667)^{2}+(1-1,125)^{2}+(2-1,958)^{2}}$
$=\quad 60,828$

Centroid $_{3=}$

$\sqrt{(3-9,25)^{2}+(1-1,083)^{2}+(3-4,667)^{2}+(1-1,125)^{2}+(2-1,958)^{2}}$

$$
=\quad 41,911
$$

Centroid $_{4}=$

$\sqrt{(3-9,25)^{2}+(1-1,083)^{2}+(3-4,667)^{2}+(1-1,125)^{2}+(2-1,958)^{2}}$

\begin{tabular}{|r|r|r|r|r|}
\hline \multicolumn{5}{|c|}{ centroid 2 } \\
\hline 23,189 & 2 & 6,838 & 2,108 & 1,054 \\
\hline \multicolumn{5}{|c|}{41,911}
\end{tabular}

Centroid $5=$

$\sqrt{(4-9,25)^{2}+(1-1,083)^{2}+(4-4,667)^{2}+(1-1,125)^{2}+(2-1,958)^{2}}$

$$
=\quad 28,078
$$

Hingga seterusnya data diperhitungkan sampai data yang 60 dan hasil dari data perhitungan yang dilakukan sebagai berikut.

Tabel 4.4: Hasil Perhitungan Gaji dan Pengelompokan Data Iterasi ke-2

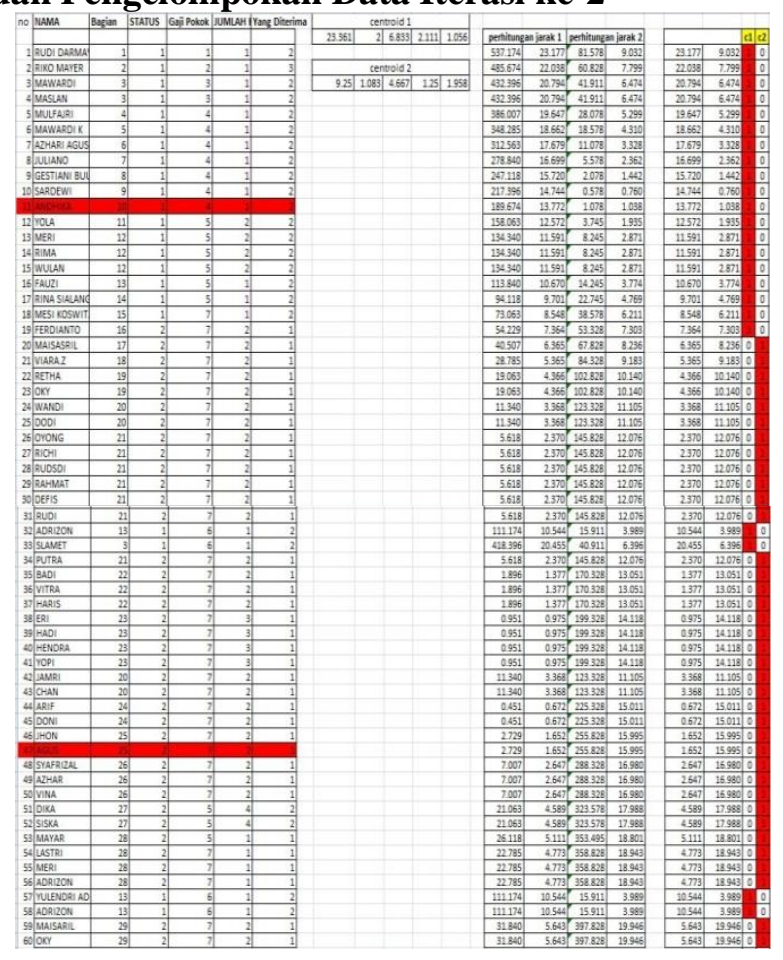

Setelah dilakukan iterasi ke-2 ternyata hasilnya masih berbeda, maka lakukan iterasi ke-3 untuk membandingkan letak posisi hasil cluster 1 dan cluster 2. Jika posisinya tidak berubah maka iterasi berikutnya tidak perlu dilakukan lagi. Untuk melakukan iterasi ke-3 maka tentukan cluster baru terlebih dahulu.

Didapatkan hasil cluster baru sebagai berikut 
Centroid $1=$

Lakukan iterasi, kemudian tentukan posisi centroid baru dengan cara menghitung ratarata dari data-data yang berada pada centroid yang sama.

2. Melakukan Pencarian Iterasi 3

Pada pembahasan ini dilakukan pencarian iterasi 3, dengan melakukan perhitungan sebagai berikut :

\begin{tabular}{|c|c|c|c|c|c|}
\hline Pusatcluster 1 & 8,913 & 1,043 & 4,565 & 1,217 & 2 \\
\hline Pusatcluster 2 & 23,189 & 2 & 6,838 & 2,108 & 1,054 \\
\hline
\end{tabular}

b. Perhitungan gaji data 1 terhadap pusat cluster.

Perhitungan pusat cluster terhadap data 1 dengan penjelasan sebagai berikut:

$$
D i j=\sqrt{\left(X_{1 i}-X_{1 j}\right)^{2}+\left(X_{2 i}-X_{2 j}\right)^{2}+\cdots+\left(X_{k i}-X_{k j}\right)^{2}}
$$

Perhitungan gaji dari data ke-1 terhadap pusat cluster :

\section{Centroid $1=$}

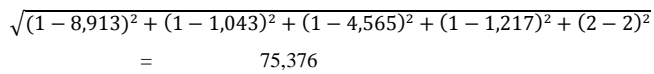

Centroid $2=$

$\sqrt{(2-8,913)^{2}+(1-1,043)^{2}+(2-4,565)^{2}+(1-1,217)^{2}+(3-2)^{2}}$

Centroid $3=$

$\sqrt{(3-8,913)^{2}+(1-1,043)^{2}+(3-4,565)^{2}+(1-1,217)^{2}+(2-2)^{2}}$

$$
=\quad 37,463
$$

Centroid 4=

$\sqrt{(3-8,913)^{2}+(1-1,043)^{2}+(3-4,565)^{2}+(1-1,217)^{2}+(2-2)^{2}}$
$=\quad 37,463$

Centroid $5=$

$\sqrt{(4-8,913)^{2}+(1-1,043)^{2}+(4-4,565)^{2}+(1-1,217)^{2}+(2-2)^{2}}$

$$
=\quad 24,507
$$

Perhitungan gaji dari data ke-2 terhadap pusat cluster: $\sqrt{(1-23,189)^{2}+(1-2)^{2}+(1-6,838)^{2}+(1-2,108)^{2}+(1-1,054)^{2}}$
$=\quad 529,563$

Centroid $2=$

$\sqrt{(2-23,189)^{2}+(1-2)^{2}+(2-6,838)^{2}+(1-2,108)^{2}+(3-1,054)^{2}}$ 478,401

Centroid $3=$

$\sqrt{(3-23,189)^{2}+(1-2)^{2}+(3-6,838)^{2}+(1-2,108)^{2}+(2-1,054)^{2}}$

$$
=425,455
$$

Centroid $4=$

$\sqrt{(3-23,189)^{2}+(1-2)^{2}+(3-6,838)^{2}+(1-2,108)^{2}+(2-1,054)^{2}}$

$$
=425,455
$$

Centroid $5=$

$\sqrt{(4-23,189)^{2}+(1-2)^{2}+(4-6,838)^{2}+(1-2,108)^{2}+(2-1,054)^{2}}$

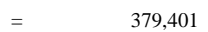

Hingga seterusnya data diperhitung kan sampai data yang 60, Setelah didapatkan cluster baru pada iterasi ke-2 maka dilakukan clustering pada iterasi ke-3 yang mana hasil cluster tetap mengalami perubahan terlihat hasil perhitungan pada tabel 4.5 Dan hasil dari data perhitungan yang dilakukan sebagai berikut

\section{Tabel 4.5 : Hasil Perhitungan Gaji dan Pengelompokan Data Iterasi ke-3}
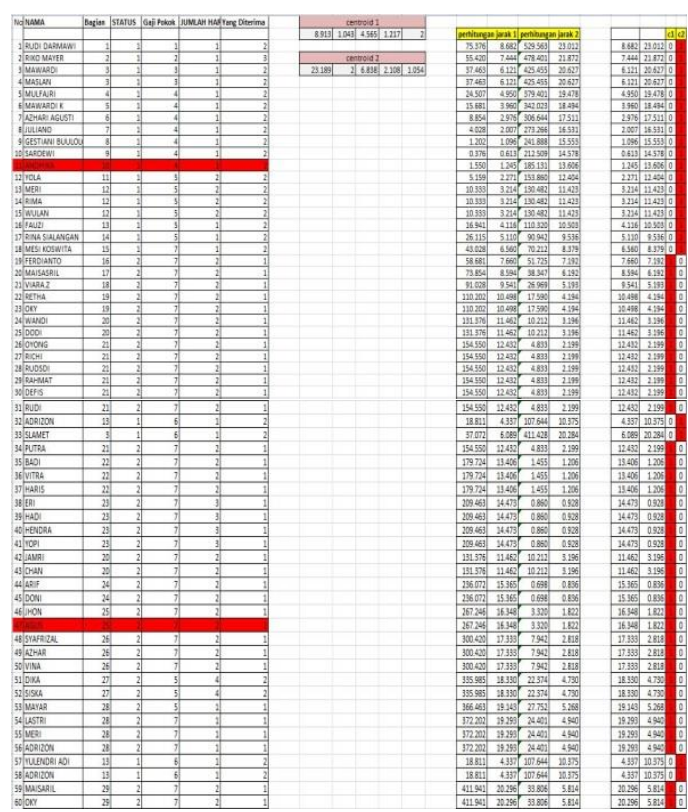

Setelah dilakukan iterasi ke-3 ternyata hasilnya masih berbeda, maka lakukan 
iterasi ke-4 untuk membandingkan letak posisi hasil cluster 1 dan cluster 2. Jika posisinya tidak berubah maka iterasi berikutnya tidak perlu dilakukan lagi. Untuk melakukan iterasi ke-4 maka tentukan cluster baru terlebih dahulu.

Didapatkan hasil cluster baru sebagai berikut

\begin{tabular}{|l|l|l|r|r|r|}
\hline \multicolumn{7}{|c|}{ centroid 2 } \\
\hline 8.591 & 1 & 4.455 & 1.182 & 2.045 \\
\hline \multicolumn{6}{|c|}{ centroid 2 } \\
\hline 23 & 2 & 6.842 & 2.105 & & 1.053 \\
\hline
\end{tabular}

\section{Melakukan Pencarian Interasi 4}

Pada pembahasan ini dilakukan penccarian interasi 4 , dengan melakukan perhitungan sebagai berikut :

c. Perhitungan gaji data 1 terhadap pusat cluster.

\begin{tabular}{|c|c|c|c|c|c|}
\hline Pusat cluster 1 & 8,591 & 1,000 & 4,455 & 1,182 & 2,045 \\
\hline Pusat cluster 2 & 23,000 & 2 & 6,842 & 2,105 & 1,053 \\
\hline
\end{tabular}

Perhitungan pusat cluster terhadap data 1 dengan penjelasan sebagai berikut:

$$
D i j=\sqrt{\left(X_{1 i}-X_{1 j}\right)^{2}+\left(X_{2 i}-X_{2 j}\right)^{2}+\cdots+\left(X_{k i}-X_{k j}\right)^{2}}
$$

Perhitungan gaji dari data ke-1 terhadap pusat cluster :

centroid $1=$

$\sqrt{(1-8,591)^{2}+(1-1)^{2}+(1-4,455)^{2}+(1-1,182)^{2}+(2-2,045)^{2}}$

Centroid $2=$

$\sqrt{(2-8,591)^{2}+(1-1)^{2}+(2-4,455)^{2}+(1-1,182)^{2}+(3-2,045)^{2}}$
$=\quad 50,409$

Centroid $3=$

$\sqrt{(3-8,591)^{2}+(1-1)^{2}+(3-4,455)^{2}+(1-1,182)^{2}+(2-2,045)^{2}}$
$=\quad 33,409$

Centroid $4=$

$\sqrt{(3-8,591)^{2}+(1-1)^{2}+(3-4,455)^{2}+(1-1,182)^{2}+(2-2,045)^{2}}$
$=$

Centroid $5=$ $\sqrt{(4-8,591)^{2}+(1-1)^{2}+(4-4,455)^{2}+(1-1,182)^{2}+(2-2,045)^{2}}$
$=\quad 21,318$
Perhitungan gaji dari data ke-2 terhadap pusat cluster :

Centroid $1=$

$\sqrt{(1-23)^{2}+(1-2)^{2}+(1-6,842)^{2}+(1-2,105)^{2}+(2-1,053)^{2}}$

Centroid $2=$

$\sqrt{(2-23)^{2}+(1-2)^{2}+(2-6,842)^{2}+(1-2,105)^{2}+(3-1,053)^{2}}$
$=470,460$

Centroid $3=$

$\sqrt{(3-23)^{2}+(1-2)^{2}+(3-6,842)^{2}+(1-2,105)^{2}+(2-1,053)^{2}}$

Centroid $4=$

$\sqrt{(3-23)^{2}+(1-2)^{2}+(3-6,842)^{2}+(1-2,105)^{2}+(2-1,053)^{2}}$

Centroid $5=$

$\sqrt{(4-23)^{2}+(1-2)^{2}+(4-6,842)^{2}+(1-2,105)^{2}+(2-1,053)^{2}}$
$=372,197$

Hingga seterusnya data diperhitungkan sampai data yang 60, Setelah didapatkan cluster baru pada iterasi ke-3 maka dilakukan clustering pada interasi $\mathrm{n}$ ke-4 yang mana hasil cluster tidak mengalami perubahan terlihat hasil perhitungan pada table 4.6 sehingga perulangan dihentikan. Dan Hasil dari data perhitungan yang dilakukan sebagai berikut.

\section{Tabel 4.6 : Hasil Perhitungan Gaji dan Pengelompokan Data Interasi ke-4}
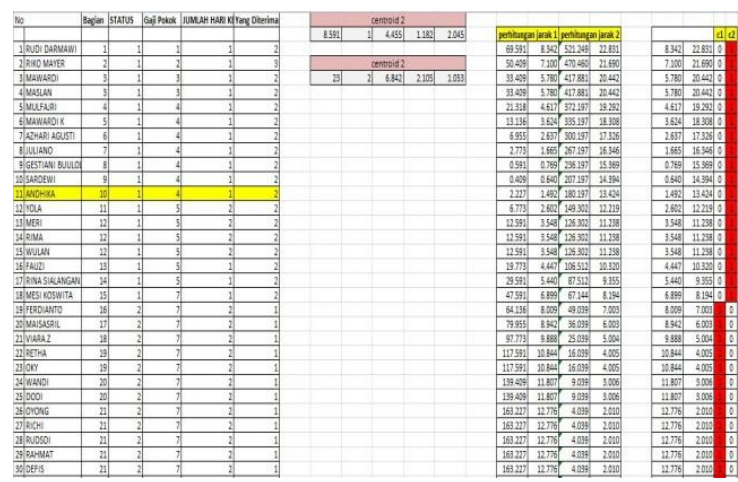

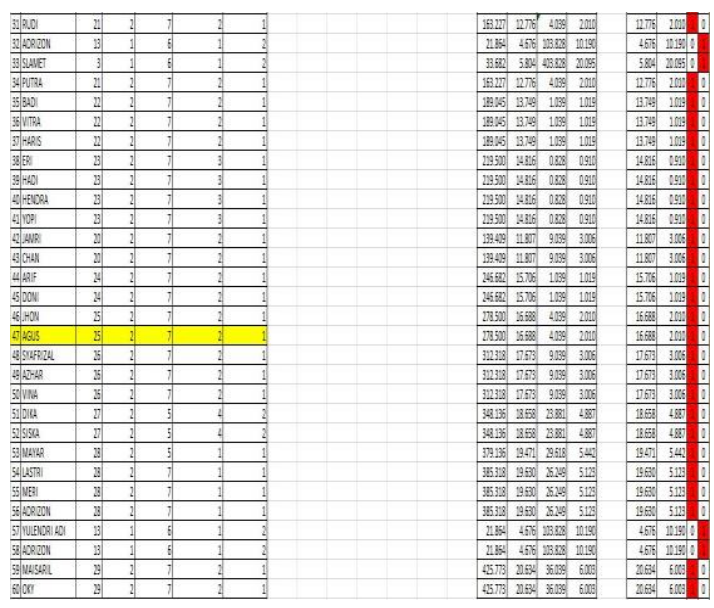

Pada interasi ke-3 dan interasi ke-4 hasil cluster tidak berubah maka perulangan tidak dilakukan lagi. Dapat ditarik kesimpulan bahwa cluster 0 terdiri 22 orang karyawan, cluster 1 terdiri dari 38 orang karyawan . Terlihat pada Tabel 4.7

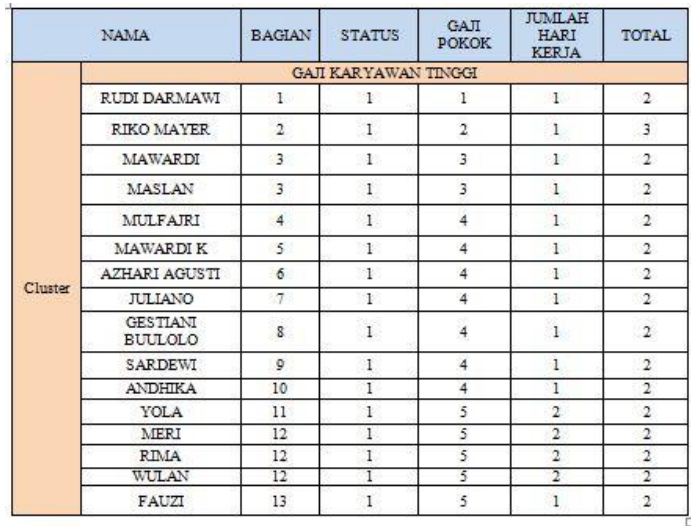

\begin{tabular}{|c|c|c|c|c|c|c|}
\hline & JAMRI & 20 & 2 & 7 & 2 & 1 \\
\hline & CHAN & 20 & 2 & 7 & 2 & 1 \\
\hline & ARIF & 24 & 2 & 7 & 2 & 1 \\
\hline & DONI & 24 & 2 & 7 & 2 & 1 \\
\hline & JHON & 25 & 2 & 7 & 2 & 1 \\
\hline & AGUS & 25 & 2 & 7 & 2 & 1 \\
\hline & SYAFRIZAL & 26 & 2 & 7 & 2 & 1 \\
\hline & AZHAR & 26 & 2 & 7 & 2 & 1 \\
\hline & VINA & 26 & 2 & 7 & 2 & 1 \\
\hline & DIKA & 27 & 2 & 5 & 4 & 2 \\
\hline & SISKA & 27 & 2 & 5 & 4 & 2 \\
\hline & MAYAR & 28 & 2 & 5 & 1 & 1 \\
\hline & LASTRI & 28 & 2 & 7 & 1 & 1 \\
\hline & $\begin{array}{l}\text { RNAA } \\
\text { SLALANGAN }\end{array}$ & 14 & 1 & 5 & 1 & 2 \\
\hline & $\begin{array}{l}\text { MESI } \\
\text { KOSWITA }\end{array}$ & 15 & 1 & 7 & 1 & 2 \\
\hline Cluster 1 & ADRIZON & 13 & 1 & 6 & 1 & 2 \\
\hline & SLANET & 3 & 1 & 6 & 1 & 2 \\
\hline & $\begin{array}{l}\text { YULENDRI } \\
\text { ADI }\end{array}$ & 13 & 1 & 6 & 1 & 2 \\
\hline & ADRIZON & 13 & 1 & 6 & 1 & 2 \\
\hline & & & AW: & & & \\
\hline & FERDIANTO & 16 & 2 & 7 & 2 & 1 \\
\hline & MAISASRI & 17 & 2 & 7 & 2 & 1 \\
\hline & VIARA.Z & 18 & 2 & 7 & 2 & 1 \\
\hline & RETHA & 19 & 2 & 7 & 2 & 1 \\
\hline & $\mathrm{OKY}$ & 19 & 2 & 7 & 2 & 1 \\
\hline & WANDI & 20 & 2 & 7 & 2 & 1 \\
\hline & DODI & 20 & 2 & 7 & 2 & 1 \\
\hline & OYONG & 21 & 2 & 7 & 2 & 1 \\
\hline & RICHI & 21 & 2 & 7 & 2 & 1 \\
\hline & RUDSDI & 21 & 2 & 7 & 2 & 1 \\
\hline & RAHMAT & 21 & 2 & 7 & 2 & 1 \\
\hline & DEFIS & 21 & 2 & 7 & 2 & 1 \\
\hline & RUDI & 21 & 2 & 7 & 2 & 1 \\
\hline & PUTRA & 21 & 2 & 7 & 2 & 1 \\
\hline & BADI & 22 & 2 & 7 & 2 & 1 \\
\hline & VITRA & 22 & 2 & 7 & 2 & 1 \\
\hline Cluater 2 & HARIS & 22 & 2 & 7 & 2 & 1 \\
\hline & ERI & 23 & 2 & 7 & 3 & 1 \\
\hline & HADI & 23 & 2 & 7 & 3 & 1 \\
\hline & HENDRA & 23 & 2 & 7 & 3 & 1 \\
\hline & YOPI & 23 & 2 & 7 & 3 & I \\
\hline & JAMRI & 20 & 2 & 7 & 2 & 1 \\
\hline & MERI & 28 & 2 & 7 & 1 & 1 \\
\hline Custer? & ADRIZON & 28 & 2 & 7 & 1 & 1 \\
\hline & MAISARII & 29 & 2 & 7 & 2 & 1 \\
\hline & OKY & 29 & 2 & 7 & 2 & 1 \\
\hline
\end{tabular}

\section{IMPLEMENTASI DAN PENGUJIAN}

Setelah dilakukan penganalisaan data seperti penjelasan pada bab sebelumnya maka langkah selanjutnya adalah melakukan implementasi. Implementasi dilakukan dengan menggunakan aplikasi RapidMiner 6.2 yang akan membantu mempermudah dalam pengelompokan gaji karyawan tetap dan kontrak yang akan membantu dalam proses pengambilan keputusan.

\subsection{Hasil Pengujian Clustering}

Pada Cluster Model (Clustering) dapat dilihat jumlah dari ke-4 cluster.

Pada Cluster Model (Clustering) ini dapat dilihat jumlah dari ke-2 cluster adalah 
cluster 1 sebanyak 22 items. Cluster 2 sebanyak 38 items. Keseluruhan data berjumlah 60 items.

\section{Cluster Model}

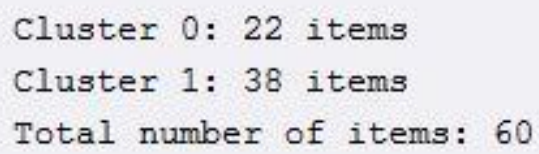

\section{Gambar 5.1 Tampilan Cluster Model (Text View)}

Pada centroid table dapat kita lihat bahwa cluster 1 merupakan kelompok karyawan yang bergaji rendah, dan cluster 2 kelompok karyawan yang bergaji tinggi. Hal ini dapat dibaca pada centroid masingmasing cluster pada attribute nilai rata-rata.

\begin{tabular}{|l|l|l|}
\hline \multicolumn{1}{|c|}{ Attribute } & \multicolumn{1}{c|}{ cluster_0 } & \multicolumn{1}{c|}{ cluster_1 } \\
\hline Bagian & 8.591 & 23 \\
\hline STATUS & 1.136 & 1.658 \\
\hline Gaji Pokok & 4.500 & 6.289 \\
\hline JUMLAH HAI & 1.318 & 1.868 \\
\hline Yang Diterir & 1.955 & 1.447 \\
\hline
\end{tabular}

Gambar 5.2 Tampilan Centroid Table

\section{KESIMPULAN DAN SARAN}

\subsection{Kesimpulan}

Berdasarkan analisa dan pengujian menggunakan Software RapidMiner pada PT Indomex Dwijaya Lestari, maka dapat diambil beberapa kesimpulan sebagai berikut :

1. Metode Clustering K-Means dapat membantu mengelompokkan gaji karyawan berdasarkan faktor-faktor yang mempengaruhi kinerja karyawan dalam bekerja sehingga membantu proses administrasi PT Indomex Dwijaya Lestari.

2. Didapatkan 2 kategori gaji karyawan, yaitu bergaji kategori tinggi dan bergaji kategori rendah dimana masing-masing cluster memiliki nilai rata-rata yang berbeda.
3. Penggunaan Algoritma k-means Clustering dapat membantu dan mempermudah dalam pencarian informasi

4. Aplikasi RapidMiner mampu mengatasi persoalan-persoalan dalam proses pengelompokan gaji karyawan, dari pada melakukan pencarian hasil secara manual karena kesalahan dalam proses pencarian oleh Administrator.

\subsection{Saran}

Untuk pengembangan dalam penelitian berikutnya maka dituliskan saransaran sebagai berikut :

1. Faktor-faktor yang mempengaruhi rendah atau tingginya gaji karyawan dapat ditambahkan sehingga pemahaman terhadap data karyawan lebih luas lagi.

2. Pada pengembangan penelitian selanjutnya dapat dilakukan dengan jumlah data yang lebih besar lagi.

3. Aplikasi RapidMiner ini merupakan suatu software yang userfriendly dan dapat digunakan untuk membantu mengelompokkan data.

4 Sofware RipadMiner dimanfaatkan pada bidang yang lebih luas lagi. Karena dengan menggunakan sofware ini dalam aplikasi pekerjaan sehari-hari dapat membantu aktifitas pekerjaan .

\section{DAFTAR PUSTAKA}

Ahmad Sanmorino. 2012. Clustering Batik Images using Fuzzy C-Means Algorithm Based on LogAverage Luminance. Faculty of Computer Science, Universitas Indonesia.

Amita Verma, Ashwani kumar. 2014. Performance Enhancement of K-Means Clustering Algorithms for High Dimensional Data sets. International Journal of Advanced Research in Computer Science and Software Engineering Research Paper Available online at: www.ijarcsse.com 
Angga Ginanjar Mabrur, Riani Lubis. 2012. Program Studi Teknik Informatika Fakultas Teknik dan Ilmu Komputer Universitas Komputer Indonesia.

Emerensye S. Y. Pandie. 2012. Implementasi Algoritma data mining K-Nearset Neighbor (K-NN) dalam pengambilan keputusan pengajuan kredit. Jurusan Ilmu Komputer, Fakultas Sains dan Teknik, Universitas Nusa Cendana

J Oyelade O, O Oladipupo O, C Obagbuwa I (2010), "Penerapan algoritma K-Means Clustering untuk prediksi kinerja akademik mahasiswa"

Noticewala Maitry dan Dinesh Vaghela. 2014. Survey on Different Density Based Algorithms on Spatial Dataset. International Journal of Advance Research in Computer Science and Management Studies Research Article / Paper / Case Study
Available online at: www.ijarcsms.com

Nurhayati. 2014. Metode Rough Set untuk melihat perilaku suami yang menjadi akseptor KB vasetomi. Program StudiTeknik Informatika, STMIK Kaputama Binjai.

Ramesh Singh Yadava1, P.K.Mishra2. 2012. Performance Analysis of High Performance k-Mean Data Mining Algorithm for Multicore Heterogeneous Compute Cluster. International Journal of Information and Communication Technology Research ISSN 2223-4985

Sankar Rajagopal. 2011. Customer data Clustering using data mining technique. Enterprise DW/BI Consultant Tata Consultancy Services, Newark, DE, USA 